Josef van Ess*

\title{
Unfertige Studien 6: Der Brudermord des Kain aus theologischer Sicht
}

https://doi.org/10.1515/asia-2020-0003

\section{Unconcluded Studies: The Fratricide of Cain from a Theological View}

Abstract: The story of Cain and Abel as it is told in the Qur'ān (Q 5:27-32), which follows closely that in the Bible (Gen 4:1-16), became the topic of various discussions among early Muslim theologians, especially Abel's statement when threatened by Cain: "I wish you to take both your sin and my sin and become one of the companions of the Fire." In the context of civil war, Abel's pacifism became a paradigm of ideal behavior, and the notion of ridding oneself of sin through victimhood appeared attractive. It was used as a model in stories concerned with battles between Muslims, such as the battle of al-Harra (683 CE), in which many Qurayshi notables and Qur'ān reciters from Medina were killed by the Syrian army. According to advice from the prophet Muhammad, the correct behavior would have been not to participate in the fighting and, in the face of death, to quote Abel's words. Whoever acts in this manner attains Paradise. However, some theologians denied the possibility that the burden of somebody's sin could be transferred to another. The story was thus reinterpreted. In his commentary on the Qur'ān, al-Ṭabarī (d. 923 CE) proposed that Abel's sentence should be understood differently: "I wish you to take your [previous] $\sin [\mathrm{s}]$ and the sin against me ...", since he could accept neither that Abel committed a sin, nor the transfer of sin to somebody else.

Stichwörter: Kain und Abel, Mord, Bürgerkrieg, Pazifismus, Islam

Dieser Beitrag ist nicht mehr als ein Versuch, einige Bemerkungen, die ich en passant in den vorhergehenden Arbeiten gemacht habe, in einen neuen Zusammenhang zu stellen. Ich gehe aus von einem kurzen Koranabschnitt, Sure 5:2730; dabei lege ich Übersetzung und Kommentar von R. Paret zugrunde. Die Perikope ist in ihrem größeren Kontext kürzlich auch von Michel Cuypers behandelt worden, vornehmlich mit Bezug auf ihre rhetorische Struktur: Le

*Corresponding author: Josef van Ess, Emeritus, Liegnitzer Straße 11,72072 Tübingen, Deutschland. E-mail: josef-van-ess@uni-tuebingen.de 
festin. Une lecture de la sourate al-Mā’ida (Paris 2007), dort S146-170. ${ }^{1}$ Zum Inhalt ist vieles Wichtige von H. Busse gesagt worden, in EQ I 270 ff. unter dem Lemma „Cain and Abel“, zum Material als solchem auch in der ebenda genannten Dissertation von W. Bork-Qaysieh, Die Geschichte von Kain und Abel in der sunnitisch-islamischen Überlieferung. Untersuchung von Beispielen aus verschiedenen Literaturwerken unter Berücksichtigung ihres Einflusses auf den Volksglauben (Berlin 1993). Ich habe diese Arbeiten mit Gewinn benutzt. Jedoch geht es mir um etwas anderes, die Frage nämlich, wie in dem narrativen Material zum Thema, das sich im Laufe der Jahrhunderte angesammelt hatte, von den neuen Leuten (den Muslimen also) die Akzente gesetzt und verschoben wurden.

Dabei stehen für mich die frühe Aufnahme und Verwertung eines einzigen Verses (Sure 5:29) im Vordergrund. Der Gewährsmann, dem ich dabei in erster Linie das Wort gebe, ist Tabarī (gest. 310/923). Er hat zu der genannten Stelle nicht nur in seinem Tafsīr zahlreiche Überlieferungen zusammengestellt, ${ }^{2}$ sondern auch in seinem Geschichtswerk auf diese Weise die Anfänge des Menschengeschlechtes rekonstruiert. ${ }^{3}$ Aber er geht beiderorts nicht auf die gleiche Weise vor. Der Korankommentar bewegt sich vom Grundsätzlichen zum Komplexen; Tabarī verfolgt in ihm die exegetischen Probleme, so wie sie sich in ihrem logischen Zusammenhang im Laufe der Zeit gestellt haben. In dem historischen Werk dagegen liegt ihm vor allem an einer möglichst stringenten Schilderung des Geschehens; der Meinungsstreit der Exegeten tritt in den Hintergrund. Ich raffe das Material, um schnell zu meinem Problem zu kommen, beginne aber mit Vers 27.

Und verlies ihnen der Wahrheit entsprechend die Geschichte von den beiden Söhnen Adams ! (Damals) als sie (jeder für sich) ein Opfer darbrachten. Vom einen von ihnen wurde es (bei Gott) angenommen, vom andern nicht. Der sagte: 'Totschlagen werde ich dich'. Er (d. h. sein Bruder) sagte: 'Gott nimmt nur von den Gottesfürchtigen (etwas) an'.

Namen werden hier nicht genannt. Die Adressaten dieser Offenbarung bedurften ihrer auch nicht. Die Geschichte war einfach und in großen Zügen bekannt. Sie wird an dieser Stelle nur um ihres paradigmatischen Charakters willen erzählt oder besser: evoziert, ins Gedächtnis gerufen. Țabarī liefert im Kommentar die Namen dann sofort nach: Hābīl und Qābīl. ${ }^{4}$ In seinem Ta'rīh - und nur dort erfahren wir zudem, daß manche Experten (vermutlich solche, die mit der

1 Englische Übersetzung (von P. Kelly): The Banquet. A Reading of the Fifth Sura of the Qur'an (Miami, Convivium Press 2009), dort S. 191-200.

2 Țabarī 1954-: 10: 201 ff. nr. 11,704 ff.

3 Țabarī 1879-1901: 1: 137 ff. / übs. Tabarī 1989: 307 ff.

4 Ṭabarī 1954-: 10: 201, 7. 
alttestamentlichen Tradition vertraut waren) hinter der Form Qābül, die in Angleichung an Hābīl/Abel entstanden war, das Original Qain (ibn Ādam) oder Qāyin erkannten, wo das $y \bar{a}$ ' hätte als $b \bar{a}$ ' verlesen sein können. ${ }^{5}$ Der Streit zwischen den Brüdern wird dann „ethnologisch“ erklärt: Abel war ein Hirte, Kain dagegen ein Bauer oder Landwirt, der „Mann hinter dem Pflug“ (șāḥib alhart). ${ }^{6}$ Konflikte zwischen Seßhaften und Nomaden, die in Zeiten der Not mit ihren Herden auf das Ackerland übergriffen, waren einem Orientalen nichts Neues; die Bibel sieht das genauso. ${ }^{7}$ Der Streit entstand, weil Kains Opfer nicht angenommen wurde und er nicht wollte, daß sein Bruder die Blamage herumerzählte. ${ }^{8}$ Abel war als Nomade ja der geborene Nachrichtenvermittler.

Aber warum hat Gott Kains Opfer nicht angenommen? Es lag nicht daran, daß Er etwas gegen Seßhafte als solche oder den Ackerbau gehabt hätte. Es spielte auch keine Rolle, daß Kain ihm kein „Schlachtopfer“ anbot, sondern Feldfrüchte. Das waren Sachverhalte, die in frühislamischer Zeit längst akzeptiert waren und den Realitätssinn der damaligen Exegeten nicht mehr auf die Probe stellten. ${ }^{9}$ Vielmehr wird als Grund angegeben, daß Kain geizig war und bloß minderwertige Produkte seiner Aussaat ( $\min$ ardali zar'ihī) opferte. ${ }^{10}$ Nur: Warum kamen die beiden Brüder überhaupt auf die Idee, einen derartigen Opferwettstreit zu veranstalten und Gott damit herauszufordern? Das war eine Frage, für die nun in erster Linie Tabarīs Weltgeschichte Interesse zeigt. ${ }^{11}$ Opfer waren am Anfang der Zeiten ja noch nicht vorgeschrieben; sie mußten im eigentlichen Sinne erst einmal erfunden werden. Darüber, wie das abgelaufen

5 Ṭabarī 1879-1901: 1: 137, 8 ff. / übs Ṭabarī 1989: 307 mit Anm. 863; vgl. EI²: 3: 13f. s. v. Hābīl wa Kāābl (G. Vajda). Man muß allerdings berücksichtigen, daß Abel auf hebräisch Hebel heißt und nicht Hābīl; die Assimilation hat sich also auch in umgekehrter Richtung ausgewirkt.

6 Țabarī 1954-: 10: 202f. nr. 11795; auch schon nr. 11,704.

7 Genesis 4:2.

8 Und damit Kains Ruf schädigte; vgl. Țabarī 1954-: 10: 203f. nr. 11,706 sowie Ṭabarī 18791901: 1: 143, 10 ff. und vorher / übs Ṭabarī 1989: 313 (mit einem Familienisnād, der von Ibn Sa'd über mehrere Generationen auf Ibn 'Abbās zurückführt).

9 Zwar gab es im Islam kein Erntedankfest. Aber man glaubte, daß Adam, nachdem er aus dem Paradies verstoßen worden war, auf Erden Landwirtschaft betrieben hatte wie Kain (Ibn Qutaiba 1969: 17, 5). Die Frucht vom Baume der Erkenntnis war, wie manche glaubten, nur ein Weizenkorn gewesen, das Adam auf den Geschmack gebracht hatte (vgl. Kleine Schriften III 2518, Anm. 105). Im Arabischen ließ sich šagar(a) nicht nur als „Baum“, sondern auch als „Kraut, Pflanze“ verstehen (vgl. Lane 1863-1893: 1507a).

10 Țabarī 1954-: 10: 205 nr. 11,713 und 11,716f.; auch schon nr. 11,711 (Muǧāhid nach Ibn 'Abbās). Zur jüdischen Überlieferung vgl. Sidersky 1933: 17. Man wird annehmen dürfen, daß Seßhafte schon damals als besitzgierig galten, im Vergleich zur Großzügigkeit und Freigebigkeit der Beduinen.

11 Im Tafsìr wird sie nur angedeutet; s. u. S. 458. 
war, hatten schon viele Generationen nachgedacht; die Muslime waren da im Grunde nur Nachzügler. Jedoch ließ sich mit etwas Scharfsinn und gewisser Lebenserfahrung das Bild weiter verfeinern. Wir werden uns damit zur Einleitung kurz beschäftigen müssen.

Man hatte die in der Bibel überlieferten Geschehnisse seit langem schon in ein historisches Konstrukt hineinzustellen versucht, bei dem Heiraten eine zentrale Rolle spielten. ${ }^{12}$ Adam und Eva hatten ja, nachdem sie der Sorglosigkeit des Paradieses verlustig gegangen waren, für eine schnelle Bevölkerung der Erde sorgen müssen. Dazu halfen zahlreiche Schwangerschaften, die jeweils mit Zwillingen endeten, stets einem Jungen und einem Mädchen. Adam verheiratete dann immer einen der Knaben mit einem Mädchen aus einer andern Schwangerschaft; so kam es zu Nachwuchs, ohne daß man sich wegen der Inzucht zuviel Gedanken hätte machen müssen. Das Ergebnis waren, wie man unter Ethnologen zu sagen pflegt, sog. „Kreuzkusinenehen“. Sie waren in frühislamischer Zeit unter Seßhaften längst üblich: bint 'amm-Heiraten, mit denen die Großfamilien Fremde außenvor und ihr Geld beisammen hielten. Der Unterschied zu den arabischen Verhältnissen war nur der, daß bei den Kindern Adams das Elternpaar stets dasselbe blieb. Jedoch schien im Rahmen des Möglichen dem Inzestverbot mit dem genannten Konstrukt auch für die Urzeit Genüge getan.

Muhammad b. Ishāā, der Verfasser der Prophetenbiographie (gest. 150/767), rechnete mit 20 Schwangerschaften; ${ }^{13}$ er kam also auf insgesamt 40 Kinder eine geheiligte Zahl. Jedoch gab es auch andere Kalkulationen; Tabarī will gehört haben, daß man von 20 auf 120 erhöhte, wobei Kain mit seiner Schwester Qalīma das erste Paar waren und ein gewisser Abū l-Mugìit mit seiner Schwester Amat al-Mugīit das letzte. ${ }^{14}$ Kain und Abel wurden also nicht als gleichaltrig

12 Ṭabarī 1879-1901: 1: 137, 11 ff. in mehreren Versionen, deren erste offenbar von Suddī (gest. 127/745; vgl. Juynboll in $\mathrm{EI}^{2}:$ 9: 762 s. n.) verbreitet und von diesem auf Ibn 'Abbās und Ibn Mas'ūd zurückgeführt wurde. Auch in Țabarī 1954-: 10: 205 f. nr. 11,714 (nach Ibn Ishāq) und 11,715 (nach Suddī, wie im Ta'rīh), nur nicht zu Anfang der dortigen Ausführungen. Nach Ibn Qutaiba 1969: 17, 10 ff. ist Wahb b. Munabbih für die islamische Überlieferung der maßgebliche Ausgangspunkt; dazu jetzt ausführlich Pregill 2008: $242 \mathrm{ff}$.

13 Ṭabarī 1879-1901: 1: 146, 8 ff. / übs Ṭabarī 1989: 317.

14 Ṭabarī 1879-1901: 1: 146, 6 f. (ohne Isnād) / übs. Țabarī 1989: 316. Der Name Qalīma für Kains Zwillingsschwester kommt bei Țabarī auch an früherer Stelle schon vor (Ṭabarī 18791901: 1: 144, 2f.). Er findet sich im übrigen auch bereits in der „Schatzhöhle“(Me'ārat Gazzē), einem frühchristlichen Pseudepigraphon, das auf Syrisch abgefaßt ist. Jedoch verbindet er sich dort mit der Schwester Abels; die Schwester Kains heißt stattdessen Lebūdā (vgl. Bezold 18831888: 8). In diesem Text taucht im übrigen auch die Kreuzehen-Geschichte im Ansatz bereits auf. Zu seiner Bedeutung für die arabische Überlieferung jetzt Pregill 2008: 245 und 257; vgl. auch Sidersky 1933: 17 und Stillman 1974: $234 \mathrm{f}$. Ein älterer Beleg für das Schema ist das 
angesehen; Kain war der Ältere. Adam hatte sich nun vorgestellt, daß Abel die „Zwillingsschwester“ Kains ehelichen solle, und Kain (der als älterer Bruder ein gewisses Mitspracherecht für sich in Anspruch nehmen konnte) war damit nicht einverstanden. Er wollte seine Schwester selber heiraten. ${ }^{15}$ So kam es zu einem Streit, der irgendwie geschlichtet werden mußte. Der Vorschlag, von Gott selber ein Zeichen zu verlangen, soll von Adam gekommen sein. ${ }^{16}$ Aber Kain hatte sich dann doch nicht damit abgefunden, daß das Opfer des jüngeren Bruders angenommen worden war, und die Sache hatte ein schreckliches Ende genommen. Adam war, wie man meinte und auch in dem biblischen Bericht vorausgesetzt schien, bei dem Opfer selber nicht zugegen gewesen. Er hatte sich, so dachten die Muslime, zu einer Reise aufgemacht. Er hatte sich nämlich Mekka einmal ansehen wollen; Gott hatte ihm gesagt, daß Er sich dort ein Haus gebaut habe die Ka'ba natürlich. ${ }^{17}$

Das Konstrukt regte zu weiteren Spekulationen an. So ist z. B. in einem späteren Text, einer Variante der Sindbadgeschichte, von einem Riesen Ūğ die Rede, der die Frucht einer Ehe Kains mit seiner Schwester 'Anāq gewesen sei; ${ }^{18}$ dahinter steckt der „Og von Basan“, dessen Riesengestalt man aus den Spuren einer Megalithkultur im Ostjordanland erschlossen ${ }^{19}$ und dessen Schwester ihren Namen von den „Enakitern“ des AT ihren Namen erhalten hatte. ${ }^{20}$ Der Inzest wurde also, sobald es nur noch um Monster (Og) oder Bösewichter (Kain) ging, nicht mehr ausgeschlossen. In dem extremší itischen K. al-Haft wal-azilla heißt es, daß nicht etwa Abel die Schwester Kains heiraten sollte, sondern Kain es war, der aktiv wurde, indem er die Tochter Abels heiraten wollte. ${ }^{21} \mathrm{Da}$ ist Adam also gar nicht mehr im Spiel. Jedoch ist das Schema mißverstanden;

Jubiläenbuch, eine antik-jüdische Schrift aus der Mitte des 2. Jh's, die uns vor allem in einer äthiopischen Übersetzung zugänglich ist (englische Übs. Charles 1902; deutsch etwa zur gleichen Zeit von E. Littmann in: Kautzsch 1900, 2: 31-119), jedoch schon in den Qumran-Texten zitiert wird (RGG ${ }^{4}$ 4: 594 f.: K. Berger). Zur Gestaltung des Problems jetzt auch Phenix 2013.

15 Daß er dies dann auch tat, steht schon in den Pirqē de R. Eliezer (Charles 1902: 51). Es war ein bewußtes Fehlverhalten.

16 Țabarī 1954-: 10: 206, 5 ff., nach der Version des Ibn Isḥāq. So auch in der Schatzhöhle (Bezold 1883-1888: 8).

17 Țabarī 1879-1901: 1: 138, 4 f. / übs. Ṭabarī 1989: 308; auch Ṭabarī 1954-: 10: 207, 4 f. in nr. 11,715. Die Schwierigkeit dabei war, daß ja eigentlich erst Abraham die Ka'ba gebaut hatte. Darum stellte man die Sache später so dar, daß Adam (der ja virtuell schon ein Muslim war) die Pilgerfahrt habe machen wollen; Gott habe dazu dann einen Edelstein aus dem Paradies herabgesandt, der die Stelle der Ka'ba einnahm (Ta'labī 2006: 47). Wahrscheinlich ist der schwarze Stein gemeint.

18 Marzolph 2017: 129.

19 Vgl. Dt. 3:11 und RGG3 I 903 f. s. v. Basan (H. W. Hertzberg).

20 Vgl. Dt. 2: $10 \mathrm{f}$.

21 Asatryan 2017: 34. 
Töchter waren darin ursprünglich nicht vorgesehen. Für uns sind diese Auswüchse nicht wichtig. Hervorzuheben ist allenfalls, daß man nie über genug Namen verfügte, um das Schema auszufüllen. Ibn Ishạa hat dies klar eingestanden: Man kenne nur die Namen von 15 Männern und 4 Frauen; das reiche nicht aus ${ }^{22}$ Zudem erhob sich bei einem der Söhne Adams, nämlich bei Seth, der in der Seitenüberlieferung neben dem Alten Testament seit langem schon eine besondere Rolle spielte, das Problem, daß es $\mathrm{zu}$ ihm anscheinend gar keine Zwillingsschwester gegeben hatte. ${ }^{23}$ Ibn Sa'd machte dann doch eine solche ausfindig, die Hazūrā geheißen habe; ${ }^{24}$ sie kommt auch schon im äthiopischen Jubiläenbuch vor. ${ }^{25}$

Zeit, um die zahlreichen Schwangerschaften im Leben des ersten Elternpaares unterzubringen, hatte man an sich genug; Adam soll über 900 Jahre alt geworden sein. ${ }^{26}$ Man konnte sich darum auch fragen, ob das „Kreuzehen“Verfahren bei Kain und Abel von Adam zum erstenmal praktiziert worden war. Er hätte dann noch keine weitere Auswahl gehabt. Kain hätte den Sinn der Sache vielleicht auch gar nicht verstanden, und Abel wäre nicht in der Lage gewesen, seinerseits zu verzichten und sich eine andere Frau zu suchen. Das war für die Schuldfrage nicht ganz unwichtig. Manche Experten gingen davon aus, daß weitere Zwillingspaare schon auf Erden lebten, bevor Kain und Abel geboren wurden, ${ }^{27}$ und von Hasan al-Bașrī wollte man sogar gehört haben, der Brudermord habe sich erst viel später ereignet, als es die Kinder Israels schon gab. Als Begründung habe er angeführt, daß ja Adam, nicht Abel der erste Mensch gewesen sei, der den Tod geschmeckt habe. Auch das Opfern habe man erst im Laufe der Zeit eingeführt. ${ }^{28}$ Das war nun allerdings mit der

22 Ṭabarī 1879-1901: 1. 146, 11 ff. / übs Ṭabarī 1989: 317.

23 Dieser Einwand kam von Juden, mit denen man sich wohl darüber unterhalten hatte (Ṭabarī 1879-1901: 1: 152, 20 / übs Ṭabarī 1989: 324). Zu Seth auch Bezold 1883-1888: 8f. und EI² 9: 489 f.; auf ihn ging letzten Endes das Menschengeschlecht zurück, da Abel keine Nachkommen hatte und die des Kain in der Sintflut umkamen.

24 Oder 'Azūrā; vgl. Ṭabarī 1879-1901: 1: 153, 2 mit Anm. a / übs. Ṭabarī 1989: 324.

25 Charles 1902, $31=$ IV 8.

26 Ṭabarī 1879-1901: 1: 160, 5 ff. / übs. Țabarī 1989: 331); so auch in der Schatzhöhle (Bezold 1883-1888: 9). Die Tausend, die an sich nur „wie ein Tag“ waren, hat Adam nicht erreicht; nach dem Jubiläenbuch fehlten ihm daran 70 Jahre (Charles 1902: 55). Das „exakte“ Alter wären danach 930 Jahre gewesen.

27 Țabarī 1954-: 10: 206, ult. in nr. 11,715. Immerhin meinte man zu wissen, daß Adam schon 125 Jahre alt war, als Kain den Abel ermordete (Ṭabarī 1879-1901: 1: 152, 18 f. / übs Ṭabarī 1989: 324). 28 Ṭabarī 1954-: 10: 208 nr. 11,719 = Ṭabarī 1879-1901: 1: 143, 18 ff. / übs. Ṭabarī 1989: 314. Zum Isnād vgl. Țabarī 1989: 314, Anm. 890. Mitgespielt hat vielleicht noch, daß nach Vers 32 das Verbot der gewaltsamen Tötung nicht etwa Adam, sondern den „Kindern Israels“ geoffenbart wurde. 
Grundtendenz der koranischen Perikope schwer zu vereinbaren; denn wenn dort „die Geschichte von den beiden Söhnen Adams“ erzählt wurde (Vers 27), so klang das nicht danach, als ob es schon weitere „Kinder Adams“ gegeben habe. Tabarī kann denn auch mit der Hypothese überhaupt nichts anfangen: „Alle Kenner der historischen Überlieferung (ahl al-ahbār was-siyar) und alle Exegeten (ahl al-'ilm bit-tafsīr)“ seien sich einig, daß zwei leibliche Söhne Adams (ibnay $\bar{A}$ dam li-șulbihī, also nicht etwa spätere Israeliten) gemeint seien. ${ }^{29}$

Umgekehrt erklärte man sich manchmal den Altersvorsprung Kains damit, daß er noch im Paradies zur Welt gekommen war. Er war also ebenso wie seine Zwillingsschwester gewissermaßen adliger Herkunft; unter diesen Umständen gab man eine Frau nicht ohne Weiteres her. ${ }^{30}$ Außerdem sei seine Schwester recht hübsch gewesen; er wollte sie darum selber heiraten - und setzte sich damit natürlich über das Inzestverbot hinweg. ${ }^{31}$ Wie auch immer es sich verhielt, der Plan ging nicht auf. Kain mußte nach dem Mord das Weite suchen; er wurde, wie es in der Bibel heißt, „unstet und flüchtig auf Erden“32 Allerdings glaubten manche dennoch, daß er mit Qalīmā zusammen die Flucht ergriffen habe. Es verschlug ihn in den Jemen, nach Aden, das in seinem Namen an den Garten Eden erinnerte. ${ }^{33}$ Kain kam also gewissermaßen von einem Paradies in ein anderes, nur daß Letzteres ihm nicht mehr soviel Annehmlichkeit bot.

Irgendwann mußte er dann ja auch ums Leben gekommen sein. Auch dafür ließ man sich etwas einfallen; er war zwar ein Mörder, aber nicht als solcher hingerichtet worden. Darum stellte man sich vor, daß seine Kinder Jagd auf ihn machten und er von einem seiner Söhne mit einem Pfeilschuß getötet worden sei. Dieser Sohn aber sei blind gewesen (und habe deswegen nicht gesehen, was er tat). $\mathrm{Zu}$ vergleichen ist wiederum ein Bericht in der Schatzhöhle, wonach Kain von Lamech, einem seiner späteren Nachkommen (erwähnt in Gen. 4:18), getötet wurde. Lamech hatte, wie man aus Gen. 4: $23 \mathrm{f}$. (dem sog. „Lamechlied“) erschloß, später auch seinen eigenen Sohn getötet. Dasselbe tut dann auch der Blinde in der arabischen Erzählung, und zwar indem er seinem Sohn ins

29 Ṭabarī 1954-: 10: 208, -4 ff.; auch Țabarī 1879-1901: 1: 145, 10 ff. / übs. Ṭabarī 1989: 316. 30 Țabarī 1879-1901: 1: 140, 16 f. / übs. Țabarī 1989: 311 = Țabarī 1954-: 10: 206, 1 f., nach Ibn Isḥāq, der sich auf gewisse Kenner der „ersten Schrift“ (al-kitāb al-auwal) beruft. Vgl. auch Ṭabarī 1879-1901: 1: 140, 1f. / übs Ṭabarī 1989: 310.

31 Vermutlich war es auch immer schon ein Risiko, ein Mädchen einem Nomaden zur Frau zu geben; man sah das Kind vielleicht nie wieder, und wenn der Beduine sie verstieß, fand sie nicht den Weg in ihre Familie zurück.

32 Gen. 4:12. Aufgenommen in Ṭabarī 1879-1901: 1: 141, 18 ff. / übs. Țabarī 1989: 312.

33 Ṭabarī 1879-1901: 1: 144, 8 / übs Ṭabarī 1989: 314. Zugrunde liegt Gen. 4:16, wonach Kain sich „im Land Nod, östlich von Eden“ niederließ. 
Gesicht schlägt. ${ }^{34}$ In beiden Fällen handelt es sich somit nicht um einen Mord, sondern nur um einen Totschlag. Daß dieser Gedankengang der Geschichte zugrundelag, wird schon in der Schatzhöhle deutlich hervorgehoben; ${ }^{35}$ in dem arabischen Bericht wird er als bekannt vorausgesetzt, aber zugleich durch die Blindheit des Täters stärker profiliert. In der Bibel dagegen wird Lamech noch verflucht. ${ }^{36}$

28: Wenn du deine Hand nach mir ausstreckst, um mich zu töten, so werde ich doch meine Hand nicht nach dir ausstrecken, um dich zu töten. Ich fürchte den Herrn der Menschen in aller Welt.

Das ist die Fortsetzung der Rede, die Abel nach dem Opfer an seinen Bruder richtet. Abel hatte, wie wir am Ende von Vers 27 erfahren, Kain mit der etwas selbstgerechten Feststellung gereizt, daß Gott nur von den Gottesfürchtigen (muttaqīn) etwas annehme. Tabarī war dazu nur wenig eingefallen. Allerdings hatte er sich erinnert, daß 'Āmir b. 'Abdallāh b. 'Abdqais, ein früher bașrischer Asket, der kein Fleisch aß und niemals eine Frau berührt hatte, beim Gedenken an Vers 27 Depressionen bekam, weil er sich nicht sicher sein konnte, selber zu den „Gottesfürchtigen“ zu gehören. ${ }^{37}$ Andere fromme Leute, z. B. 'Adī b. Tābit, ein Mann aus medinensischer Familie, der während der Statthalterschaft des Hālid al-Qasrī im Irak starb, ${ }^{38}$ hatten sich in der Gewißheit beruhigt, daß das „Opfer“ der Gottesfürchtigen nunmehr im täglichen Gebet bestehe. ${ }^{39}$

34 Ṭabarī 1879-1901: 1: 144, 13 ff. / übs Ṭabarī 1989: 315 mit Anm. 895.

35 Bezold 1883-1888: $11 \mathrm{f}$.

36 Gen. 4:23; bei Matthäus (18:23) spielt Jesus darauf an. Nach dem Jubiläenbuch findet Kain den Tod, indem sein Haus über ihm zusammenbricht (Charles 1902: 41 = IV 31); auch da gab es keinen Schuldigen.

37 Țabarī 1954-: 10: 212, 2 ff.; der Isnād dazu dann in nr. 11,725. Dieselbe Überlieferung, nur anders pointiert, auch bei Ibn Sa'd 1904-1917: 7.1: 76, 2 ff. Die Biographie, in der sich dies bei Ibn Sa'd findet, ist recht ausführlich (S73-80), enthält aber kein Todesdatum. Auch Haliffa b. Haiyāt weiß nur, daß 'Āmir „,in den Tagen Mu'āwiyas“', also vor 60/680, in Syrien gestorben sei (Haliffa 1966: 459 nr. 1543). Das geht darauf zurück, daß dieser, ein wehrfähiger Araber, zu einem unbestimmten Zeitpunkt nach Syrien abkommandiert worden war, vermutlich weil er in Bașra dadurch auffiel, daß er sich dem öffentlichen Freitagsgebet entzog und damit dem Gemeinschaftsgefühl der kämpfenden Truppe nicht entsprach (TG: 2: $87 \mathrm{f}$.). Er war damals vermutlich noch recht jung; denn als Prophetengenossen hat man ihn nie eingeordnet. Mit seinem Umzug nach Syrien verschwand er für die Iraker auf immer von der Bildfläche. Man rechnete ihn unter die bakkā'ūn; daher meine „Depressionen“. Vgl. zu ihm weiterhin Abū Nu'aim 1932-1938: 2: 87-95; EI²: 1: 441a s. n. (Ch. Pellat); Gramlich 1997: Index 398 s. n.

38 Also zwischen 106/724 und 120/738; vgl. Ḩalïfa b. Huaiyāṭ 1966: 373 nr. 1198 und Hुalīfa 19671968: 522, 6. Später findet sich das Jahr 116/734 (Ibn Ḥağar al-'Asqalānī 1907: 7: 165 f. nr. 329). Zu ihm auch Dahabī 1963-1965: 3: 61 f. nr. 5591; man warf ihm prošǐitische Sympathien vor. 39 Ṭabarī 1954-: 10: 212 nr. 11,726. 
Abel aber wollte nach dem Streit an sich halten und seine Hand nicht wider seinen Bruder erheben. Daß der Disput überhaupt eine Fortsetzung fand (und Kain nach dem mißglückten Test nicht gleich zuschlug), wird schon in jüdischen Quellen vorausgesetzt. ${ }^{40}$ Die Frage war nur, wie Abels Äußerung zu verstehen sei. Wollte er es bloß nicht zum Äußersten kommen lassen oder war er ein echter Pazifist? Handelte er also aus Prinzip oder verhielt er sich nur passiv - wie schon der Kalif 'Utmān, der ja auch, wie man glaubte, über dem Koran erschlagen worden war? Die Frage war zum Teil beantwortet, wenn man sich denjenigen anschloß, die annahmen, daß Kain seinen Bruder heimtückisch im Schlaf ermordet habe, indem er ihm mit einem schweren Stein den Schädel einschlug, dann war zumindest klar, daß es nicht vorher zu einem Handgemenge gekommen war. Ṭabarī weist darauf hin, daß zahlreiche Gelehrte (ǧamā'a min ahl al-ilm) sich den Ablauf so vorgestellt hatten. ${ }^{41}$ Aber wie konnte Abel dann wissen, daß Kain einen Mord im Sinne hatte? Noch nie hatte ja ein Mensch vorher das Blut eines andern Menschen vergossen. Manche glaubten, daß der Teufel, also Iblīs, ${ }^{42}$ Kain gezeigt habe, wie er vorgehen müsse, indem er nämlich einem Tier den Kopf zwischen zwei Steinen zerquetschte. ${ }^{43}$ Aber zu dieser pädagogischen Maßnahme kam es ja vermutlich erst nach dem Zwiegespräch der beiden Brüder. Außerdem hatte Kain, wie aus Vers 27 hervorging, Abel schon vorher wissen lassen, daß er ihn „totschlagen“ werde. Tabarī schließt daraus, daß Gott, bevor es zum Streit kam, bereits in einer Art Uroffenbarung verboten hatte, jemandes Blut zu vergießen, solange dieser nicht selber unrechtmäßig $\left(z u l m^{a n}\right)$ jemanden getötet, also einen Mord begangen hatte. ${ }^{44}$ Adam war ja nach islamischer Auffassung nicht nur der erste Mensch, sondern auch der erste Prophet. Es war die Art, wie das islamische Recht nach der talio die Tötung oder Hinrichtung eines Mörders begründete: an-nafs bin-nafs, Leben um Leben.

40 Vgl. Speyer 1931: $85 \mathrm{f}$.

41 Țabarī 1954-: 10: 214, $12 \mathrm{f}$; dazu auch ib. $221 \mathrm{f}$. nr. 11,746 und 11,748. Diese Darstellung des Hergangs findet sich im übrigen schon im Buch der Jubiläen und in jüdischen Quellen; vgl. Speyer 1931: 86, Anm. 1 und Stillman 1974: 236. Zum Felsstein als Mordinstrument auch Bezold 1883-1888: 8.

42 Beide Wörter, das deutsche wie das arabische, sind aus dem gleichen griechischen Wort abgeleitet: aus $\delta$ ı $\alpha \beta$ o $о$ s. Nur daß im Arabischen die erste Silbe weggefallen ist, weil man das $\delta \mathrm{s}$ als diejenige Partikel mißverstand, mit der im Aramäischen bzw. Syrischen der Genitiv gebildet wurde. Vgl. auch EQ: 1: 524b s. v. Devil (A. Rippin).

43 Tabarī 1954-: 10: 222 nr. 11,747-8. Das war allerdings nicht die richtige Art, ein Tier zu töten; beim rituellen Schlachten ließ man das Tier ausbluten, indem man seine Halsschlagader durchschnitt. Aber auch das wollte erst einmal gelernt sein, und Satan wußte es noch nicht besser.

44 Ṭabarī 1954-: 10: 214, 7 ff. 
Im Koran wird es am Ende der Perikope, in Vers 32, nachgetragen. ${ }^{45}$ Aber Abel kann sich vorher schon darauf beziehen. Er weiß nur noch nicht, daß Kain seine Absicht wahrmachen wird.

29: Ich möchte, daß du meine und deine Sünde auf dich lädst und so einer von den Insassen des Höllenfeuers sein wirst. Das ist der Lohn der Frevler.

Jetzt wird Abel deutlich: Kain wird in die Hölle kommen. Denn solches geschieht mit allen „Frevlern“ (zālimūn), und jemand, der unrechtmäßig (zulm $\left.{ }^{a n}\right)$ das Blut eines Menschen vergießt, ist ein Frevler. Aber nicht nur das: Wenn Kain seine Absicht wahrmacht, wird er doppelt belastet in das höllische Feuer eingehen; denn er wird nicht bloß seine eigene Schuld zu tragen haben, sondern auch die Abels, den er umgebracht hat. So zumindest hat Paret die Stelle verstanden, und er dürfte recht haben. ${ }^{46}$ Jeder Hörer oder Leser wird unbefangen das an $\operatorname{tab} \bar{a}^{\prime} a$ bi-itmī wa-itmika des Textes so interpretieren. Itrm ist „Vergehen, Sünde“; „Schuld“ ist vom Sinn her etwas weiter entfernt, aber zumindest nach deutschem Wortverständnis das, was gemeint ist. ${ }^{47}$

Damit ist natürlich vorausgesetzt, daß Abel sich einer eigenen Schuld bewußt war. Dies würde sich am ehesten mit einer Interpretation vertragen, wonach der Streit zwischen den Brüdern in ein Handgemenge ausartete; Abel wäre dann kein Pazifist gewesen und hätte sich dies auch eingestanden. Tabarī allerdings kann sich mit dieser Deutung nicht anfreunden. Von einer Schuld Abels will er nicht reden. Er legt sich darum die Worte, auf die es ankommt, grammatisch anders zurecht: Das Suffix in itmī sei, so sagt er, nicht im Sinne eines Genitivus subiectivus aufzufassen, sondern als Genitivus obiectivus, also nicht „meine Sünde“, sondern „die Sünde, die (du, Kain) mir gegenüber begangen hast“ Schon mit itmī wäre somit der Mord gemeint; für itmuka „deine Sünde“ (Singular) würden dann nur diejenigen Vergehen übrigbleiben, die Kain außerdem im Lauf seines Lebens begangen hatte. Schon sein Opfer war ja gewiß nicht ohne Grund abgelehnt worden. ${ }^{48}$ Dennoch: das ist exegetische Akrobatik - zwar scharfsinnig gedacht, aber vom primären Wortverständnis her extrem unwahrscheinlich. Tabarī läßt sich jedoch davon nicht abbringen. Die andere, für uns normale Interpretation sei ihm, so sagt er, nur einmal begegnet,

45 S. u. S29. Dort ist allerdings nicht Adam der Adressat dieser Offenbarung, sondern die Israeliten; vgl. dazu Speyer 1931: 87 f. und oben Anm. 23. Die Stelle in Sure 2 ist spät (vgl. Neuwirth 2017: 154).

46 Vgl. auch Busse in EQ: 1: 270: „wishing that Cain be held responsible for the sins of both“. 47 Diese Schuld wird, wie Paret in einer erklärenden Anmerkung hinzufügt, durch die Bestrafung Kains ,gesühnt“.

48 Dazu Busse in EQ: 1: 271b. 
bei jemandem, der sich dazu auf Muğāhid berufen habe. Muǧāhid habe itmī mit hațī’atī erklärt: „mein (d. i. Abels) Fehlgriff“ Das sei aber, so müsse man befürchten, ein Irrtum. ${ }^{49}$

Diese Aussage ist erstaunlich. Aber nur in Nebensächlichkeiten läßt Tabarī dann noch mit sich reden. Wie kann, so fragt er z. B., wenn mit itmī Kains Sünde gemeint ist, Abel „wollen“, ${ }^{0}$ daß Kain diese Sünde begehe und deswegen zur Hölle verdammt sei? Tabarīs Antwort ist etwas umständlich; aber sie läuft letzten Endes wieder auf besagte Uroffenbarung hinaus, die Gott Adam zukommen ließ, nachdem er ihn aus dem Paradies auf die Erde hatte stürzen lassen (ahbața). Abel weiß von daher, daß Mord ein schweres Verbrechen ist, welches Gott gewiß bestrafen wird. Abel wünscht also Kain nicht direkt etwas Böses, sondern will, daß die Ordnung, die Gott den Menschen auf Erden vorgeschrieben hat, eingehalten werde. ${ }^{51}$ Die Strafe folgt einem Mord denn auch gleich auf dem Fuße zumindest wenn man Muğāhid glauben darf: Ein Mörder, so habe dieser frühe Exeget (gest. 104/722) gemeint, ${ }^{52}$ werde nach seinem Tode bis zum Endgericht irgendwo (kopfüber?) an einem Bein aufgehängt, und es sei dafür gesorgt, daß ihm dabei die Sonne immerfort ins Gesicht scheint. ${ }^{53}$ Wo immer jemand später einen Mord begeht, ist Kain dafür mit verantwortlich; denn er war der erste, der das ungesetzmäßige Töten eingeführt hat (auwalu man sanna l-qatl). ${ }^{54}$ Für Tabarī ist dies ein Grund mehr, der These Hasan al-Bașrīs, daß der Brudermord in eine Zeit falle, in der Adam schon nicht mehr lebte, eine Absage zu erteilen. ${ }^{55}$

Warum Tabarī den Passus in Vers 29 umgedeutet hat, erfahren wir eher nebenbei: Gott habe ja kundgetan, daß jeder Mensch nur für sein eigenes Handeln belohnt oder bestraft werde; ${ }^{56}$ Abel habe also Kain nicht auch noch seine eigene Sündenlast aufbürden können. Țabarī beruft sich dazu auf den Konsens der Exegeten (iğmă $\bar{a}^{c}$ ahl at-ta'wīl). ${ }^{57}$ Wen er genau meint, sagt er nicht.

49 Țabari 1954-: 10: 216, 10 ff. nr. 11,736.

50 So im Arabischen: urīdu an. Paret übersetzt mit „ich möchte“.

51 Țabarī 1954-: 10: 217, 7 ff., vor allem 218, 2 ff.

$52 \mathrm{Zu}$ ihm näher Gilliot 2014.

53 Wahrscheinlich, damit er so bereits einen Vorgeschmack der Höllenhitze erhält (vgl. Ṭabarī 1954-: 10: 218, 4 ff.); Busse vergleicht in EQ: 1: 270 mit dem Prometheus-Mythos. In Busses Übersetzung von Ta'labīs 'Arā’is al-mağălis sieht der Text allerdings etwas anders aus (Ta'labī 2006: 62).

54 Ṭabarī 1954-: 10: 218f. nr. 11,738-41 (wobei in nr. 11,740 neben ihm auch der Teufel noch genannt wird). Kurz auch Țabarī 1879-1901: 1: 145, 1 ff. / übs Ṭabarī 1989: 315, wo die Isnāde der einzelnen Traditionen dann einfach zusammengefaßt werden. Vgl. dazu Juynboll 2007: 106b.

55 Țabarī 1954-: 10: 219, 8 ff.; s. o. zu nr. 11,719.

56 Das ist natürlich im Koran geschehen. Gedacht ist vermutlich an das lā taziru wäziratun wizra uhrā, das im Koran mehrfach als Leitsatz begegnet (Sure 6:164, 17:15, 35:18, 39:7, 53:38). 57 Ṭabarī 1954-: 10: 217, 3 ff. Der Koran wird allerdings hier nicht zitiert; Ṭabarī will ja auf eine Uroffenbarung hinaus. 
Aber in den auctoritates, die er für seine Ansicht bemüht, begegnet als Urheber zweimal Qatāda b. Di'āma, der Schüler des Hasan al-Bașrī. ${ }^{58}$ Das bringt uns auf die Spur. Qatāda (gest. 117/735) war wie sein Lehrer Qadarit, wenn auch nur in jenem eingeschränkten Sinne, den wir von Hasan her kennen: Alles ist vorherbestimmt (bzw. von Gott geschenkt), nur die Sünde nicht; ${ }^{59}$ für sie ist jeder selbst verantwortlich. Mit dem Koran hatte Qatāda (der ihn auswendig zitieren mußte, weil er blind war) sich viel beschäftigt, und das Material, das er im Kolleg seinen Schülern vermittelte, wirkte über Bașra hinaus. Țabarī zitiert ihn in seinem Tafsīr mit einem bestimmten Isnād (der auch an unserer Stelle, in nr. 11,731, vorkommt) mehr als 3000mal. Seine Art, mit Sure 5:29 umzugehen, leuchtete dann auch den Mu'taziliten ein. Kein Wunder also, daß Ǧubbā'ī (gest. 303/915), ein Zeitgenosse Țabarīs, das itmī in der Rede Abels sich auf dieselbe Weise gefügig machte wie dieser. ${ }^{60}$

Zur westlichen Koranexegese in diesem Punkt nur ein kurzer Exkurs: Paret äußert sich in seinem Kommentar zu der grammatischen Uminterpretation nicht; er wollte sich in seiner Koranübersetzung ohnehin von der Tafsīr-Tradition lösen. A. Th. Khoury dagegen weist auf das Problem hin (Khoury 1990-2001: 6: 80), läßt aber durchblicken, daß es sich um ein späteres Theologoumenon handelt. R. Bell übersetzt auf normale Weise („Verily I wish thee to become liable for my sin and for thine own“), läßt dann aber in seinem postum erschienenen Kommentar beide Möglichkeiten zu Worte kommen und gibt der zweiten sogar den Vorzug (ohne Tabarī oder irgendeinen andern muslimischen Exegeten zu nennen). In Abels „Schuld“, die dann an Kain hängen bleibt, möchte er eine Anspielung auf das „Kainsmal“ erkennen (Bell 1991: 1: 155). M. Cuypers behandelt auf der Suche nach der rhetorischen Struktur den Satz in mehreren konzentrischen Ansätzen (Cuypers 2009: 191 ff.). Das „Wollen“ Abels betrachtet er als Indiz für einen Fluch. Das kombiniert er dann in einem typologischen Ansatz mit jenem Fluch, den Jesus nach Mt. 23: 33-36 über die Pharisäer aussprach (S. 199; vgl. auch die Zusammenfassung S. 215f.). An einen Fluch hätte ein muslimischer Exeget natürlich nie gedacht. Kain bedauert seine Tat ja (in Vers 31); dazu Weiteres u.S. Busse weist darauf hin, daß Abel in der christlichen Tradition als Präfiguration Jesu gesehen werden konnte, allerdings nicht wegen eines Fluches, sondern wegen seiner Passivität (EQ: 1: 271a); vgl. dazu wiederum Cuypers 2009: $198 \mathrm{f}$.

58 Ṭabarī 1954-: 215 nr. 11,731-32; s. o. S. 452 f.; 457.

59 TG II $137 \mathrm{f}$.

60 Vgl. Gimaret 1994: 267, wo dies allerdings nur sekundär erschlossen ist. Ğubbā’̄ì hat im übrigen mit Ṭabarī auch die Deutung von Abels „Wollen“ (urīdu, s. o. S. 457) gemeinsam. 
Daß Ğubbā'ī ebenso wie Ṭabarī auf einem Holzweg war und der Passus in Abels Rede zu Anfang für geraume Zeit auf „normale“ Weise verstanden wurde, ohne theologische Skrupel, stellt sich heraus, wenn wir das Arbeitsfeld der Exegeten verlassen und nach Belegstellen suchen, wo das an tabü'a bi-itmì wa-itmika von Sure 5:29 in anderem Zusammenhang zitiert wird. Das geschieht schon früh im Hadīt. Im K. at-Tahrīš des Dirār b. 'Amr, das wohl in der zweiten Hälfte des 2. Jh's entstand, ${ }^{61}$ findet sich das Prophetenwort: „Sei eine der Matten (aḥlās) deines Hauses! Wenn (jemand) in feindlicher Absicht in deinen Hausbezirk (dār) eindringt, so ziehe dich in dein (eigenes) Heim (bait) zurück. Wenn er (sodann) in feindlicher Absicht in dein Heim eindringt, so ziehe dich in deine Kammer (mihda ${ }^{c}$ zurück, und wenn er in feindlicher Absicht in deine Kammer eindringt, so gib dich in seine Gewalt und sprich: 'Nimm meine und deine Schuld auf dich!'. Sei derjenige Knecht Gottes, der getötet wird, und nicht der, der tötet!“ Darauf folgt dann ein Kommentar, von dem sich vorläufig nicht mit Sicherheit sagen läßt, ob er noch dem Propheten in den Mund gelegt ist oder aus der Feder des Autors (also Dirārs) stammt: „Gott hat euch nämlich die beiden Söhne Adams zum Gleichnis gegeben. Nehmt euch den Guten von beiden zum Vorbild und meidet den Bösen! Halte dich (darum) an das Wort 'Nimm meine und deine Schuld auf dich!' Sei derjenige, dem Unrecht geschieht, und nicht derjenige, der Unrecht tut! Denn wenn jemandem Unrecht geschieht, so steht er in Erwartung des Sieges (nașr), und wenn er Unrecht tut, so (nur) in Erwartung der (jenseitigen) Strafe. Es ist besser, zu denen zu gehören, die den Sieg erwarten, als zu denen, die in Erwartung der Strafe stehen. Wenn jemand sich deines Besitzes bemächtigen und dir deine Frau rauben will, so beschwöre ihn bei Gott, und wenn er sich auf (deine Worte) nicht einläßt, so vergleiche dich mit ihm um die Hälfte deines Besitzes! Wenn er aber auch darauf nicht eingeht, so fange keinen Krieg mit ihm an, sondern trenne dich von deinem Besitz und deinen Frauen (huramuka)!“

Ich habe diesen Abschnitt früher schon einmal übersetzt; ${ }^{62}$ er steht bei Dirār im Kapitel über die Haāriǧiten. Pazifismus wird darin gepredigt und Duldsamkeit in einem Maße, wie man das kaum in einer frühislamischen Quelle erwarten würde. Man war die Bürgerkriege offenbar gründlich leid. Die „Matten“ (aḥlās) sind Grundlage für einen Sektennamen geworden, eine Gruppenbezeichnung also, die damals im Umlauf war und kurz darauf wieder aus dem religiösen Diskurs verschwand: die Hilsīya. ${ }^{63}$ Sie stand für Pazifismus und Neutralität. Wie man das itmī aus Sure 5:29 verstand, geht zwar aus dem Passus nicht unmittelbar

61 Zur Datierung vgl. jetzt meinen Nachtrag in Kleine Schriften III 2461-2500.

62 Kleine Schriften III 2576-2579.

63 Vgl. van Ess 1971: 27 nach dem K. Ușūl an-niḥal des Ğa'far b. Ḥarb. 
hervor; hier wird ja keine Exegese getrieben. Aber man muß sich den Kontext genauer anschauen. Unmittelbar vorher wird der Prophet nämlich mit einem andern Dictum zitiert: „'Wenn zwei Muslime mit ihren Schwertern aneinandergeraten und sich gegenseitig töten, so kommen sowohl der Töter als auch der Getötete in die Hölle.' Da sagte man: 'O Gesandter Gottes, natürlich der Töter. Aber warum auch der Getötete?' Er antwortete: 'Der wollte seinen Bruder (doch ebenfalls) töten'، “64 Es ist also an eine Situation gedacht, in der zwei Parteien sich ursprünglich feindlich und bewaffnet gegenüberstanden, bevor eine von ihnen die Waffen niederlegte. Zum Pazifisten wird man erst im Nachhinein, wenn man zur Besinnung kommt. Das Kapitel richtete sich ja an Hāriǧiten, und zwar in der Absicht, ihnen ein Lob auszusprechen (fi madḥ al-Hawāriğ). ${ }^{65}$ Sie waren früher einmal sichtlich aggressiv gewesen und nun, im 2. Jh. H., friedlich geworden. Da ließ sich also keine Schuld weginterpretieren. Das K. at-Tahrǐš ist vermutlich in Kūfa geschrieben; die von uns verworfene „qadaritische“ Interpretation von itmī dagegen ist bașrisch.

Allerdings läßt sich nicht leugnen, daß auch Ḍirār qadaritisch dachte. ${ }^{66} \mathrm{Um}$ sicher zu gehen, müssen wir also nach Parallelen suchen, in denen er nicht mehr im Spiele ist. Bürgerkriege verbreiteten ein solches Grauen, daß man sie nur als endzeitlich begreifen konnte. Erst wenn die Welt unterging, würde es zu jenen „Anfechtungen“ (fitan) kommen, als die man die Bürgerkriege bezeichnete. Im Șaḥị̣ des Muslim (b. al-Ḥağğāğ, gest. 261/875, also ein halbes Jahrhundert vor Tabarī) findet sich im Kapitel über „die Anfechtungen und die Zeichen der Endzeit" ein Ḥadīt, das ein gewisser 'Utmān aš-Šaḥḥām ${ }^{67}$ berichtet:

Ich und Farqad as-Sabahīi ${ }^{68}$ machten uns auf den Weg, um Muslim b. Abī Bakra ${ }^{69}$ auf seinem Landgut ( $f_{i}$ ardihī) zu besuchen. Wir traten ein und fragten: 'Hast du deinen Vater

64 Kleine Schriften III 2578: nr. 75.

65 Vgl. Kleine Schriften III 2536-2556 und 2585-2587.

66 Vgl. Kleine Schriften III 2566.

67 Offensichtlich ein Bașrier, über den sich aber kaum etwas ausfindig machen läßt. Er wird in den kanonischen Haditwerken nur an dieser Stelle genannt (vgl. Conc.: 8: 185a, im Personenindex). Anscheinend handelte er mit Fetten (šahm). In dem vorliegenden Ḥadīt ist er Gewährsmann des Ḥammād b. Zaid (gest. im Ramaḍān 179 / Nov.-Dez. 795 im Alter von 81 Jahren; zu ihm Ibn Sa'd 1904-1917: 7.2: 42, 6 ff. und Hูalīfa b. Haiyāṭ 1966: 540 nr. 1895, auch Juynboll 2007: 165-174).

68 Bașrischer Asket, gest. 131/749 an der Pest (wie Wāsil b. 'Ațā'); zu ihm näher TG: 2: 94 und Kleine Schriften I 814.

69 Ein Bruder des 'Abdarraḥmān b. Abī Bakra, der als erstes Kind eines Arabers in Bașra geboren wurde (Halīfa b. Haiyāṭ 1966: 484 nr. 1642); gest. wie sein Bruder vor 90/710 (Halīfa b. Haiyāt 1967-1968: 401, 10). Auch er kommt in den kanonischen Ḥadītwerken neben dieser Stelle nur noch einmal vor, im Musnad des Ibn Ḥanbal (Ibn Ḥanbal 18955: 5: 44, 10). 
über die Anfechtungen (am Ende der Zeiten etwas) tradieren hören?’ Er antwortete: ‘Ja. Ich habe gehört, wie Abū Bakra ${ }^{70}$ vom Propheten berichtete: 'Anfechtungen wird es (immer) geben. Dann aber kommt eine Anfechtung, in der jemand, der sitzt (d. h. sich ruhig verhält), besser dran ist als jemand, der geht (um an ihr teilzunehmen), und jemand, der in ihr geht, besser als jemand, der ihr entgegeneilt. Wenn sie herabkommt - oder: sich ereignet $^{71}$-, sollte jemand, der Kamele besitzt, sich zu seinen Kamelen begeben; jemand, der (Herden von) Kleinvieh besitzt, zu seinem Kleinvieh; jemand, der ein Landgut hat, auf sein Landgut. ${ }^{72}$ Da sagte jemand $z u$ ihm: 'Und wenn nun jemand weder Kamele noch Kleinvieh noch ein Landgut besitzt, ${ }^{73}$ o Gesandter Gottes?' Er antwortete: 'So soll er sein Schwert hernehmen und dessen Schneide mit einem Stein zerschlagen. ${ }^{74}$ Dann sollte er sehen, wie er sich retten kann! Bei Gott, habe ich mich deutlich genug ausgedrückt? (Und noch einmal:) Bei Gott, habe ich mich deutlich genug ausgedrückt? (Und wieder:) Bei Gott, habe ich mich deutlich genug ausgedrückt?'. Der Mann sagte darauf zu ihm: 'O Gesandter Gottes, wenn ich nun gezwungen werde, mich einer der beiden Schlachtreihen - oder einer der beiden Parteien ${ }^{75}$ - anzuschließen, und mich jemand mit dem Schwert erschlägt oder ein Pfeil kommt und mich tötet?'. Er antwortete: '(In diesem Fall) wird er seine und deine Schuld tragen (müssen) und in die Hölle kommen. ${ }^{76}$

Die Anspielung ist offenkundig, und auch über die Art, wie sie gemeint ist, besteht kein Zweifel. Interessant ist aber, daß Muslim sogleich hinterher anmerkt, bei Wakī‘ (b. al-Ǧarrāḥ, gest. 197/812), der das Ḥadīt mit den gleichen

70 Also der Vater, ein damals angesehener Taqafit, der eigentlich Nufai' hieß und sich als Sohn des Ḥārit b. Kalada ausgab, der im Ḥiğāz gelebt hatte und als „Arzt der Araber“ (d. h. unter den Beduinen) galt (zu ihm Ch. Pellat in: EI ${ }^{2}$ XII 354 f. und Ullmann 1970: 19f.); zum Problem der Sohnschaft vgl. Pellat 354b. Er war ein Freigelassener des Propheten und hatte sein Haus in der auch sonst gelegentlich genannten vornehmen Stephanus-Straße in Bașra; dort starb er i. J. 52/ 671. Vgl. dazu Halifa 1966: 125 nr. 367 sowie Halīfa b. Haiyāt 1967-1968: 58 f. und 259, 7 f.; Ibn Sa'd 1904-1917: 7.1: 8, 24 ff.; Ibn 'Abdalbarr 1960: 1614f. nr. 2877.

71 Das ist eine Variante: waqa'at statt nazalat.

72 Abū Bakra ist also froh, im Augenblick nicht in seinem Stadthaus zu sein, sondern auf seinem Landgut. Es gab allerdings auch ein konkurrierendes Prophetenwort, wonach man in einer Zeit der „Anfechtungen“ bei seiner Schafherde besser aufgehoben sei (vgl. Juynboll 2007: 304). Man war dann beweglicher; in einer Parallele wird das Bild erweitert zu der Vorstellung, daß man mit einem Schaf sich auf eine Alm flüchtet (Nu'aim b. Ḥammād 1991: 93 nr. 218 / übs. Aguadé 1979: 76 und jetzt The Book of Tribulations Cook 2017).

73 Also ein armer Teufel, der weder Herden hat noch ein Ackerbauer ist. Die Parallele zu Abel und Kain deutet sich hier schon an.

74 D.h. es schartig und damit unbrauchbar machen. Man vergleiche unser „Schwerter zu Pflugscharen“, das ja immerhin der Bibel entnommen ist (Micha 4:3). Aber dort ist eine Strafe gemeint, die die Heiden treffen wird: „Sie werden ihre Schwerter zu Pflugscharen und ihre Spieße zu Sicheln machen“. Kein Volk wird dann mehr lernen, Krieg zu führen. Aus muslimischer Sicht wären die Pflugscharen nur dem Mörder von Nutzen gewesen; Kain war ja Bauer. 75 Auch das ist wieder eine Variante: iḥdā l-fi'atain statt aḥad aṣ-ṣaffain.

76 Muslim 1955-1956: 2212f. (al-Fitan wa-ašrāṭ as-sā'a 13). Parallelen aus Abū Dāwūd und Ibn Māğa (die ebenfalls jeweils in den Kapiteln über die fitan stehen) in Conc. 1: 228b, ult. 
Gewährsleuten über eine andere Überlieferungskette erhielt, fehle die zweite Hälfte mit dem Zitat. ${ }^{77}$ Der Text ist offenbar gewachsen. Auch eine Parallele, die über Zuhrī läuft und textlich leicht abweicht, ${ }^{78}$ enthält nur die erste Hälfte. ${ }^{79}$ Das Zerbrechen der Schwerter ist gleichfalls ein separates Element, das sich selbständig gemacht hat. ${ }^{80}$ Das Koranzitat aber begegnet separat in einer Parallele, die Ibn Ḥanbal bewahrt hat. Rib'ī (b. Hirāš al-Ġaṭafānīi) ${ }^{81}$ hört, wie jemand beim Begräbnis des Ḥudaifa (b. al-Yamān) ${ }^{82}$ sagt:

Der da auf der Bahre liegt, hat gesagt: 'Mich beunruhigt das, was ich vom Propheten gehört habe, nicht. Wenn ihr euch bekriegt, gehe ich in mein Haus, und wenn jemand dann bei mir eindringt, sage ich einfach: Nimm meine und deine Schuld auf dich! ${ }^{83}$

Der Erzähler will darauf hinaus, daß Ḥudaifa die Kamelschlacht vorausahnte, zu der es kurz nach seinem Tode kam (wenn auch nicht in Kūfa, sondern in der Nähe von Bașra). ${ }^{84}$ Wie delikat solche Situationen waren, geht daraus hervor, daß man von demselben kinderreichen Abū Bakra, der die anfängliche Äußerung überlieferte, auch gehört haben wollte: „Wenn zwei Muslime mit den Schwertern aneinandergeraten, so kommen sowohl der Töter als auch der Getötete in die Hölle“85. Wir haben diesen Ausspruch - allerdings ohne Bezug auf

77 Muslim b. al-Ḥağğāğ 1955-1956: 2213, 8-10; also das Stück, das mit dem dreimaligen Ausruf „Bei Gott, habe ich mich deutlich genug ausgedrückt? (hal ballaġtu)“ beginnt. Zu Wakī` vgl. GAS 1: 96 f. und van Ess Unfertige Studie 4, 926, Anm. 117; er war auch auf dem Gebiet der Koranexegese tätig (GAS 1: 97, nr. 4). Wakī's Muṣannaf wird herangezogen in Ibn Ḥanbal 1946-1975: 4: 289, ult. 78 Übersetzt bei Juynboll 2007: 234a. In seinem Kommentar verweist Juynboll u. a. auf die von uns gewählte Fassung (nach Ḥammād b. Zaid).

79 Bis zu dem „Rette sich, wer kann“; vgl. Conc.: 6: 363b s. v. tumma la-yanğu in istațā'a n-nağ $\bar{a}^{\prime}$. Weiter verkürzt und verändert in Muslim b. al-Ḥağğāğ 1955-1956: 2211f. (Fitan 10-12). 80 Haitamī 1982: 300, pu. ff. (nach dem Mu ğam al-ausaṭ des Ṭabarānī). Vgl. Conc.: 2: 140a s. v. yaduqqu.

81 Zu ihm Ibn Sa'd 1904-1917: 6: 87, 3 ff. und Hुalīfa b. Ḩaiyāṭ 1966: 349 nr. 1104, jeweils mit völlig unsicherem Todesdatum (82/701?); dazu Juynboll 1991: $164 \mathrm{f}$.

82 Gest. 35/655 oder 36/656 in Kūfa; vgl. Ibn 'Abdalbarr 1966: 334 f. nr. 492.

83 Ibn Hanbal 1895: 5: 389, 15 ff. und leicht abweichend 393, 8 ff.; aufgenommen bei Haitamī 1982: $301,-5 \mathrm{ff}$.

84 Inhaltlich verwandt (und ebenfalls mit Rib`ī als erstem Tradenten) auch Ibn Hanbal 1895: 5: 387, 2 ff.: „Wer sich von der Gemeinde trennt (man färaqa l-ğamā'a), kann sich vor Gott nicht mehr blicken lassen“. Das soll Ḥudaifa dann allerdings gesagt haben, als „die Leute zu 'Utmān zogen“, also kurz vor dessen Ermordung. Äußerungen Hudaifas in diesem Sinne finden sich auch im K. al-Fitan des Nu'aim b. Hammād (vgl. Aguadé 1979: 77 f.), jedoch ohne Datierung und, wie hier, ohne den Bezug auf Sure 5:29. Weiteres Material mit Bezug auf 'Utmān bei Aguadé 1979: 79 f.; s. auch u. S. 465, $471 \mathrm{f}$.

85 Muslim b. al-Ḥaǧğāğ 1955-1956: 2213 f. (Fitan 14-15). Ähnlich auch Rib'ī b. Ḥirāš (s. o. Anm. 80) nach Abū Bakra (Muslim b. al-Ḥağğāğ 1955-1956: 2214=Fitan 16). 
Abū Bakra - auch bei Dirār b. 'Amr schon angetroffen. ${ }^{86}$ Solange jemand, wie Hudaifa, in Kūfa blieb und nicht mit 'Alī der feindlichen Heeresmacht entgegenzog, wurde dies auch nicht zum Problem. Der Hinweis auf Sure 5:29 findet sich dort dann natürlich nicht.

Dagegen wird das Koranzitat aufgenommen in einem weiteren Hadīt, das bei Muslim bewahrt ist. Da ist dann jedoch die Endzeit aus der Darstellung getilgt. Wā’il b. Ḥuğr, ein Stammesführer aus Ḥaḍramaut, der als Mitglied einer Delegation nach Medina gekommen war, ${ }^{87}$ berichtet, daß, als er gerade mit dem Propheten zusammensaß, ein Mann vorbeigekommen sei, der einen andern an einem Strick führte. ${ }^{88}$ Ersterer sagte: „Der hat meinen Bruder umgebracht, o Gesandter Gottes.“ Der Prophet fragte (den andern): „Hast du das wirklich getan?“, und dieser antwortete mit Ja. Der Prophet fragt weiter: „Wie hast du das denn gemacht?“ - „Der da und ich, wir hackten von einem Baum die Äste ab. Da beschimpfte er mich und versetzte mich in Zorn. Ich gab ihm eins mit dem Beil über den Schädel; ${ }^{89}$ da war er tot. “90 _ „Hast du etwas, womit du dich auslösen könntest?“91 - „(Nein.) Ich habe nichts außer meinem Kittel (kis $\bar{a}$ ') und meinem Beil.“ - „Nimmst du an, daß deine Stammesangehörigen (qaumuka) sich für dich einsetzen?“ - „Denen bin ich nicht wichtig genug,“ Da warf (der Prophet) dem (andern) seinen Strick wieder zu und sagte: „Da hast du den Kerl wieder“ (dūnaka șāhibaka), und der machte sich davon. Als er den Rücken gekehrt hatte, sagte der Prophet: „Wenn er ihn jetzt tötet (was an sich sein Recht ist), dann ist er wie er,“92 Da kam (der Mann) zurück und sagte: „O Gesandter Gottes, mir ist zu Ohren gekommen, du hättest gesagt: 'Wenn er ihn tötet, so ist er wie er'. Dabei habe ich ihn nur wieder mitgenommen, weil du mir das befohlen hast.“ Der Prophet darauf:

86 S. o.S. 460. Man müßte versuchen, herauszubekommen, wer jeweils diese Versionen gegeneinander lanciert hat, und aus welchem Anlaß.

$87 \mathrm{Zu}$ ihm Ibn 'Abdalbarr 1960: 1562f. nr. 2736. Er wird auch sonst als „neutraler“ Beobachter herangezogen; vgl. van Ess Unfertige Studie, nr. 5; dort Anm. 36 mit weiteren Quellen. Der Prophet soll ihm ein Landgut in Ḥaḍramaut geschenkt haben, wohl um ihn für sich zu gewinnen (Juynboll 2007: 547). Daß man Ḥuğr lesen muß und nicht etwa Hiğr (wie in Hुalifa b. Huaiyāṭ 1966: 166 nr. 485) oder Ḥağr, steht bei Ibn Ḥağar al-'Asqalānī 1964-1967: 1: 412, 2), allerdings mit dem Zusatz, daß einige spätere Rechtsgelehrte den Namen anders vokalisierten. 88 Gemeint ist ein Seil, an dem man Vieh führte, manchmal auch ein Gurt an der Vorderseite eines Kamels; dieser Strick bestand aus zusammengeflochtenen Lederstreifen. Vgl. Ibn Manẓūr 1955 (Lisān al-'Arab): 8: 352f. und Lane 1863-1893: 3032b s. v. nis'a.

89 Wörtlich: „ich schlug ihn auf das Horn (qarn)“, also die Stelle, wo bei den Tieren das Horn sitzt, die Vorderseite des Kopfes.

90 Wörtlich: „da tötete ich ihn“.

91 Gemeint ist das Blutgeld; vgl. Lane 1863-1893: 38a s. v. addā.

92 Also ebenfalls ein Mörder. 
„Willst du, daß er deine Schuld ebenso trägt wie seine eigene?“93 - „Ja gewiß (balā), o Gesandter Gottes.“94 - „Dann ist das auch so.“95 Da warf er den Strick hin und ließ ihn laufen. ${ }^{96}$

Die Geschichte gewährt einen Einblick in frühe Rechtspraxis. Muslim hat sie in sein Kapitel über die qasāma eingeordnet: ${ }^{97}$ Der Prophet wird unvermittelt um ein Urteil angegangen und muß feststellen, daß ein Mörder, der ihm vorgeführt wird, bei seinem Stamme nicht mit dem damals üblichen Kollektiveid rechnen kann, der ihn entlastet hätte. Der Bruder des Ermordeten darf also frei über ihn verfügen. Würde er jedoch Rache nehmen und den Mörder seinerseits töten, so lüde auch er Schuld auf sich, und er könnte sich nur wünschen (wie Abel bei Kain), daß diese seine Schuld dem Mörder zur Last gelegt werde. ${ }^{98}$ Das sei aber falsch gedacht. Er werde seine Schuld nicht los und komme darum als Mörder ebenfalls in die Hölle. Der präsumtive Rächer akzeptiert dieses Verdikt, das seinem eigenen Denken widerspricht, weil der Prophet für ihn eine religiöse Autorität ist; er will nicht in die Hölle kommen. Darum läßt er den Mörder (der seine Tat nicht mit einem Blutgeld sühnen kann) frei. Aus der Sicht des Erzählers nimmt der Prophet also gewissermaßen das „qadaritische“ Argument zu Sure 5:29 schon voraus; niemand darf meinen, daß er seine Schuld einem andern aufbürden könne. Die Geschichte ist wegen dieser Implikation häufig umerzählt worden; Nasā'̄ hat in seinem K. as-Sunan die Varianten gesammelt. ${ }^{99}$

93 Wörtlich: „und die deines Genossen“ (iț șāḥibika). Hier wechselt der Erzähler offenbar die Perspektive. Er hätte itmahū sagen müssen bzw. itma nafsihī; da er aber sich in den Angeredeten hineinversetzt, redet er von dem Mörder als von dem, den er mit sich führt. Der Mörder wird ja vorher schon von dem Propheten als șăhibuka bezeichnet. Dort ist die Ausdrucksweise situationsgerecht. Dennoch wäre „dein Genosse“ oder „der, den du bei dir hast“ zu abgehoben; ich habe deswegen mit „Kerl“ übersetzt. Șăḥib hat an der jetzigen Stelle einen ironischen Beiklang - wie wenn wir jemanden mit „Freundchen“ anreden.

94 Hier ist sich der Erzähler nicht sicher, daß der Angeredete balā sagte: La'allahū qāla „balā“. 95 Gemeint ist: Dann kommt ihr auch beide in die Hölle.

96 Muslim b. al-Ḥağğāă 1955-1956: 1307 f. (=Qasāma 32), zusammen mit einer verkürzten Version S. 1308 (=Qasāma 33). Erster Gewährsmann ist in beiden Fällen Wā’ils Sohn 'Alqama, über den aber nichts Näheres bekannt ist (vgl. Dahabī 1963-1965: 3: 108 nr. 5761). Das Material läuft über Simāk b. Ḥarb (gest. 123/741), der in Kūfa lebte wie die Familie Wā’ils (vgl. dazu die bei Juynboll 2007: Index 741 s. v. 'Alqama $b$. Wā'il angegebenen Stellen; zu Simāk ib. 566 ff.). $97 \mathrm{Zu}$ dieser vorislamischen Praxis vgl. EI²: 4: 689f. (Pedersen / Linant de Bellefonds) und Crone 1984; auch van Ess 2014: 50 ff.

98 Hier ist vermutlich an die öffentliche Meinung gedacht. Der Rächer kann darauf hoffen, daß man sagen wird, der Mörder sei selber schuld, wenn er seinerseits getötet werde. Die „qadaritische“ Uminterpretation von Sure 5:29 räumt auch damit auf.

99 Nasā'î 2000: 769 f. (=Qasāma 6 nr. 4741-4748). Nr. 4744 und 4746 kommen dabei der Version bei Muslim sehr nahe; in nr. 4747-48 kommt Wā’il b. Ḥuğr nicht mehr vor. Weitere Stellen s. Conc.: 4: 285a. Ausgelöst wurde das Problem u. a. durch den unklaren Bezug von itm 
Wir wissen vorläufig nicht, wann und wo diese „Arbeit am Text“ als nötig empfunden wurde. Aber wir werden annehmen dürfen, daß es geschah, weil die Diskussion über die Koranstelle immer komplexer wurde. Trotz allem ist diese selber noch nicht uminterpretiert.

Wir versagen es uns, weiter in Einzelheiten zu gehen, und kehren $\mathrm{zu}$ den endzeit-bezogenen Hadīten zurück. Dort läßt sich nämlich u. U. die Chronologie leichter fassen. Die frühe muslimische Gemeinde hatte sich an den kriegerischen Erfolg ihrer Religion im Grunde gewöhnt und war auch geneigt, darin Gottes Willen am Werke zu sehen. Aber es kam dann immer wieder zu Rückschlägen, in denen die Gemeinde die Waffen gegen sich selber richtete und den äußeren Erfolg zu zerstören drohte. Das waren die Augenblicke, in denen die Reflexion erwachte und man sich überlegte, ob nicht die Endzeit (in der vielleicht schon manche Anhänger des Propheten zu leben gemeint hatten ${ }^{100}$ ) nun wirklich angebrochen sei. Es war darum leicht, diese Erwartungen auf den Propheten zu rejizieren. Man stellte dann zwar jedesmal nachträglich fest, daß das Leben trotzdem weitergegangen war und irgendwie wieder in normalen Bahnen verlief. Muhāsibī (gest. 243/857) hat diese Erfahrung in einem historischen Rückblick auch einmal festgehalten; wir haben den Passus vor kurzem zugänglich gemacht. ${ }^{101}$ Aber die Situation, auf die man sich jeweils bezog, hat doch in den genannten Weissagungen Spuren hinterlassen. Der Ausspruch des Ḥudaifa b. al-Yamān wurde so plaziert, daß man die Kamelschlacht assoziieren mußte, die bei seinem Tode schon ihre Schatten vorauswarf. ${ }^{102}$ Auch wenn man erzählte, wie der Kalif 'Utmān ermordet worden war, fügte man vermutlich nicht ohne Absicht hinzu, daß er im Koran lesend den Tod fand; der Hörer sollte sich vielleicht fragen, welche Stelle er denn gerade gelesen haben könnte. ${ }^{103}$ Es handelt sich da natürlich um narrative Kunstgriffe, die sich chronologisch schlecht fassen lassen. Aber es gab zumindest ein Ereignis, das zu einer endzeitlich gefärbten Darstellung und einem Bezug auf Sure 5:29 in besonderer Weise herausforderte, weil „Koranleser“ (qurrā') an ihm unmittelbar beteiligt waren: die Schlacht auf der Harra im Jahr 63/683. Auch

șāhibika (s. o. Anm. 92). Die Stelle wird auch bei Ibn al-Ațī 1963: behandelt (1: 159, 12 ff. s. v. $b$ $w^{\prime}$ '); aber er hatte einen abweichenden Text vor sich.

100 Dazu näher van Ess 2001: $180 \mathrm{ff}$.

101 In: van Ess Unfertige Studien, nr. 4: 929-931.

102 Daß sein Tod und die Kamelschlacht zeitlich nahe beieinander lagen, wird allerdings auch anderswo vorausgesetzt; vgl. Ibn Sa'd 1904-1917: 3.2: 19, ult. ff. (in der Biographie des Muhammad b. Maslama al-Anșārī).

103 Wir wissen allerdings nicht, ob diese Frage je gestellt wurde. Die Quellen äußern sich dazu nicht. 
da hatten Muslime gegen Muslime gestanden, und von einem gottgewollten ǧihād konnte auf beiden Seiten keine Rede sein. Im Vorspann eines Hadītes, das Haitamī bei Bazzāz ${ }^{104}$ gefunden hat, erzählt ein gewisser Abū l-Ašcat aṣȘan'ānī Folgendes:

Yazīd b. Mu'āwiya ${ }^{105}$ schickte mich mit einigen Prophetengenossen zu 'Abdallāh b. Abī Aufā ${ }^{106}$. Ich sagte: 'Was befehlen denn die Leute so (in der Angelegenheit)?' Er antwortete: 'Abū l-Qāsim ${ }^{107}$ gab mir als letztes Vermächtnis mit auf den Weg, ich solle, wenn ich in so etwas hineingeriete, auf jemanden losgehen, ${ }^{108}$ (dann aber) mein Schwert zerbrechen und mich in mein Haus zurückziehen ( $a q^{\prime} u d a$ fi baitī). Wenn (der andere aber) mich in mein Haus verfolge, sagte er, so solle ich mich in meine Kammer zurückziehen, und wenn er mich auch dahin verfolge, so solle ich auf die Knie fallen und sagen: 'Nimm meine und deine Schuld auf dich, so daß du einer der Insassen des Höllenfeuers sein wirst. Das ist der Lohn der Frevler' (Sure 5: 29). - Ich habe mein Schwert längst zerbrochen, und wenn (der Betreffende) in mein Haus eindringt, ziehe ich mich in meine Kammer zurück, und wenn er mich bis in meine Kammer verfolgt, dann lasse ich mich auf die Knie nieder und sage genau das, was der Prophet mir gesagt hat, daß ich sagen soll. ${ }^{109}$

Die Szene spielt in Kūfa. Der Kalif, ein Sohn Mu'āwiyas und der erste unter den Umaiyaden, der aufgrund eines noch unerprobten dynastischen Prinzips an die Regierung gekommen war, will erfahren, wie man in der Stadt (und im Irak überhaupt) darüber denkt, daß er den Widerstand der Medinenser, die ihm die Huldigung versagt hatten, mit bewaffneter Gewalt gebrochen hat. Der Erzähler stellt sich vor, daß man 'Abdallāh b. Abī Aufā befragt habe, einen kūfischen Prophetengenossen, von dem man wußte, daß er in der Stadt derjenige gewesen war, der aus dieser Gruppe am längsten den Propheten überlebt hatte. ${ }^{110}$ Auch zur Zeit der Schlacht wäre er schon nicht mehr jung gewesen; der Tod Muhammads lag ein halbes Jahrhundert zurück. Dennoch gab man ihm in der späteren

104 Muḥammad b. Muẓaffar b. Mūsā al-Bazzāz (286/899 - 379/989), Angehöriger einer Bag̉dāder Kaufmannsfamilie, die mit Leinenwaren handelte und aus Sāmarrā' stammte (vgl. Ta'rīh Bağdād 3: 262-264 nr. 1355). Bruchstücke seiner Ḥadìtsammlungen sind in der Zāhirīya-Bibliothek, Damaskus erhalten (GAS 1: 205).

105 Das ist der Kalif Yazīd I. (reg. 60/680-64/683).

106 Gest. angeblich 86/705 oder 87/706, in sehr hohem Alter. Er war Medinenser, hatte sich jedoch schon früh in Kūfa niedergelassen; vgl. Hualifa b. Haiyāt 1966: $242 \mathrm{nr} .684$ und Ibn 'Abdalbarr 1960: 870 f. nr. 1478, auch Ibn Sa'd 1904-1917: 4.2: 36 f. und 6: 13, 1 ff.

107 Das ist der Prophet. Der Gebrauch der kunya signalisiert ein besonderes Vertrauensverhältnis.

108 An a'mida ilā ahadin; der Text benutzt hier wie im Folgenden indirekte Rede.

109 Haitamī 1982: 7: 300, 15 ff.

110 Ibn 'Abdalbarr 1960: 870, apu. f. 
biographischen Literatur noch weitere 20 Jahre; ${ }^{111}$ der Erzählung ist das nicht anzumerken. ${ }^{112}$ Der Abgesandte des Kalifen, der i. J. 63/683 noch einige andere Prophetengenossen auf seine Reise aus Syrien hatte mitnehmen können, ${ }^{113}$ war Jemenit, also - wie der Hörer annehmen mußte - vermutlich kein Freund der nordarabischen Qais, die in großer Zahl 'Abdallāh b. az-Zubair im Hiğāz unterstützten und bald in der Schlacht von Marğ Rāhiṭ (64/684) mit den Kalb, die auf Seiten Marwāns standen, aneinandergeraten würden. ${ }^{114}$ 'Abdallāh b. Abī Aufā läßt erkennen, daß er das Vorgehen des Kalifen zwar nicht billigt, aber seinerseits keinen Widerstand geleistet hätte, weil der Prophet das nicht gewünscht hatte.

$\mathrm{Zu}$ beachten ist dabei, daß in der Weisung des Propheten vorausgesetzt wird, daß der Adressat sich anfangs in die Auseinandersetzung einmischt (an a'mida ilā ahad); die Passivität ist also nicht prinzipiell geboten, sondern nur post festum. Die Situation, bei der sie hätte praktiziert werden müssen, war ja völlig aus dem Ruder gelaufen. Bei der Schlacht auf der Harra waren zahlreiche vornehme Quraišiten und nicht wenige medinensische „Koranleser“ gefallen - zwar nicht ganz soviele, wie man später behauptete, ${ }^{115}$ aber doch eine beachtliche Anzahl, unter denen die Träger der religiösen Überlieferung und des „kulturellen Gedächtnisses“ besonders auffielen. Die Medinenser hatten vermeiden wollen, daß die Gegner in die Oase eindrangen; es wäre zu Straßenkämpfen und zu Zerstörungen im Fruchtland gekommen. Darum bauten sie draußen vor der Stadt eine Verteidigungslinie auf, auf dem Lavafeld in der Wüste, wo nichts mehr wuchs und wo man sich sonst nur zum Regengebet versammelte. ${ }^{116}$ Dabei versprach man sich viel von einem Konzept, das man dem Propheten abgeschaut hatte: Man zog einen Graben (handaq) auf der steinigen Fläche, wie schon Muhammad dies getan hatte, als die heidnischen Mekkaner i. J. 5/627, zwei Jahre nach der Schlacht am Berge Uhud, gegen Medina vorrückten. ${ }^{117}$ Aber die

111 Er war im Alter erblindet. Zu seiner Langlebigkeit vgl. Juynboll 1991: 168.

112 Für den Erzähler spielt auch keine Rolle, daß der Kalif schon wenige Monate nach der Schlacht gestorben war. Er hätte unmittelbar, nachdem ihn die Nachricht von ihrem Ausgang in Syrien erreichte, die Delegation abgeschickt haben müssen.

113 Um wen es sich handelte, wird nicht gesagt; sie hätten gleichfalls nicht mehr jung sein können.

114 Vgl. EI²: 6: 544 f. s. v. (N. Elisséeff); Rotter 1992: 133 ff. - Der Abgesandte heißt übrigens in einer Überlieferung ähnlichen Inhalts (bei Ibn Ḥanbal 1895: 4: 226, 3 ff.) Aš‘at aṣ-Ṣan'ānī (also ohne „Abū“). Er reist da auch nicht nach Kūfa, sondern nach Medina und trifft nur einen gewissen Ziyād anstatt des wesentlich bekannteren (und angeseheneren) Ḥudaifa b. al-Yamān. 115 Vgl. Rotter 1992: 52.

116 Vgl. van Ess Unfertige Studien, nr. 1: 1393-1394.

117 Vgl. EI²: 4: 1020 s. v. Khandak (W. M. Watt). Das Wort ist persischen Ursprungs, und der Rat zu dieser Maßnahme kam angeblich auch von einem Perser, Salmān al-Fārisī (EI²: 12: 701). Mit dem Graben sollte vor allem die feindliche Kavallerie außer Gefecht gesetzt werden. 
„fundamentalistische“ Strategie ${ }^{118}$ scheiterte. Die syrischen Truppen, kampferprobt wie sie waren, machten kurzen Prozeß; in weniger als einem Tag war die Schlacht vorbei. In Medina beklagte man viele Tote, und die Stadt wurde geplündert.

Auch das hatte der Prophet angeblich vorhergesehen. Er habe auf einen der befestigten Familiensitze (utum) ${ }^{119}$ in Medina herabgeschaut und dabei die Worte fallen lassen: „Könnt ihr euch vorstellen, woran ich jetzt denke (wörtl.: was ich jetzt sehe)? Ich sehe, wie es mitten unter euren Häusern zu Anfechtungen/Unruhen kommt, so dicht wie Hagelschauer.“120 Die Legendenbildung war also in vollem Gange. Sie dürfte recht bald eingesetzt haben - jedenfalls wohl, bevor der erlittene Schock von der nächsten Katastrophe überdeckt wurde. Der Überlieferer dieses letzten Hadītes ist bezeichnenderweise kein Kūfier, sondern ein Medinenser: Abū Sa'īd al-Hुudrī; wir werden auf ihn zurückzukommen haben. Jedoch begegnet der Text auch mit anderen Isnāden. Die von Juynboll übersetzte Version geht von Usāma b. Zaid aus ${ }^{121}$ und wird von Zuhrī aufgenommen. Man wollte natürlich wissen, wer die Ehre gehabt hatte, mit dem Propheten draußen vor der Stadt auf einer Anhöhe zu sitzen. ${ }^{122}$

Der Kern der zuvor übersetzten Geschichte begegnet uns noch einmal, nun ohne den Bezug auf Sure 5:29, dafür aber unter expliziter Nennung der Harra: „Der Gesandte Gottes hat gesagt: 'Wenn du siehst, wie die Leute sich um eines weltlichen (Vorteiles) willen bekriegen, so begib dich mit deinem Schwert zu dem mächtigsten Felsstein in der Harra und beklopfe es damit, bis es zerbricht. Dann setz dich (iğlis) in dein Haus, bis eine sündige Hand ${ }^{123}$ oder ein unvermeidliches Todesgeschick dich ereilt!“ Der Berichterstatter fügt dann ebenso wie 'Abdallāh b. Abī Aufā hinzu: „Da tat ich, wie mir der Gesandte Gottes befohlen hatte.“124 Er ist mit Bedacht gewählt; Muhammad b. Maslama, ein medinensischer Prophetengenosse

118 Dazu Kister 1977: 48; auch Rotter 1992: 50.

119 Es handelt sich um burgartige Bauten, die in ihrer Architektur an die Hochhäuser in Haduramaut oder im Jemen erinnern; ihre Dächer ragten unter den Palmenhainen heraus. Vgl. das Bild bei Krämer, Geschichte des Islam, S. 8, wo allerdings nicht Medina, sondern ein jemenitisches Dorf gezeigt wird.

120 Ich habe etwas frei übersetzt; wörtlich: „(so häufig) wie Regentropfen“. Vgl. Muslim b. alḤağğāğ 1955-1956: 2211 (Fitan 9); Parallelen in Conc.: 1: 67a. Übersetzt bei Juynboll 2007: 572. $121 \mathrm{Zu}$ ihm EI²: 10: 913 s. n. (V. Vacca).

122 Muhammad schaut ja auf die Oase herab wie Jesus auf Jerusalem, wobei dieser ebenfalls die Zerstörung der Stadt (und das Weltende) vorhersagt (Mk. 13:3-27). Usāma ist ein geeigneter Adressat, weil er sich später von allen Bürgerkriegen ferngehalten hat (s. u.).

123 „Hand“ ist hier im Sinne von „Verfügungsgewalt“ zu verstehen; so wurde das Wort auch im islamischen Recht gebraucht.

124 Haitamī 1982: 7: 300, pu. ff. nach dem Mu'ğam al-ausaț des Ṭabarānī. Das Prophetenwort etwas abweichend und mit „Uhud“ statt „al-Ḥarra“ auch bei Ibn Sa'd 1904-1917: 3.2: 19, 25 (wo aber irrtümlich ahad vokalisiert ist statt Uhud). 
(gest. Șafar 46/April-Mai 666), war dafür bekannt, daß er sich ein Schwert aus Holz geschnitzt hatte und weder bei der Kamelschlacht noch bei Șiffin dabeigewesen war. ${ }^{125}$ Wie Usāma b. Zaid, Sa'd b. Abī Waqqāṣ und 'Abdallāh b. 'Umar rechnete man ihn zu den mu'tazilūn, die sich von allen „Anfechtungen“ ferngehalten hatten. ${ }^{126}$ Zum Zeitpunkt der Schlacht auf der Harra war er allerdings bereits seit anderthalb Jahrzehnten tot.

Abū Sa'īd al-Hुudrī dagegen, dem wir oben schon begegneten, soll noch an ihr teilgenommen haben. Er wäre damals schon Anfang 70 gewesen. Als die Schlacht verloren war, soll er sich in der felsigen Gegend in einer Höhle verkrochen haben. Als ihn ein syrischer Soldat, natürlich viel jünger als er, dort aufstöberte, habe er ihm den Satz aus Sure 5:29 entgegengehalten; dieser sei daraufhin so verdutzt gewesen, daß er ihn am Leben ließ. ${ }^{127}$ Wahrscheinlich hatte ihm der alte Mann nur leidgetan; aber der Erzähler setzt voraus, daß er sich im Koran soweit auskannte, um zu wissen, womit er hier konfrontiert wurde. Die Geschichte stimmt freilich ohnehin nicht; denn in einer andern Quelle ${ }^{128}$ steht, Abū Sa'īd habe sich in seinem Haus aufgehalten und die Plünderung nicht verhindern können. Sure 5:29 kam nach dieser Darstellung dann nicht zum Einsatz, obwohl das Zitat da doch ebensogut am Platze gewesen wäre. Aber wie immer Abū Sa'īd sich auch verhalten haben mag, er handelte so, wie man es nach den Haditen von ihm erwartete. Was in Wirklichkeit geschah, bleibt uns verschlossen. Wir wissen nicht einmal mit Sicherheit, ob er damals noch lebte. ${ }^{129}$

$125 \mathrm{Zu}$ ihm Ibn 'Abdalbarr 1960: $1377 \mathrm{nr} .2344$ und Ibn Sa'd 1904-1917: 3.2: 18, 16 ff. Er soll sein Schwert schon zerbrochen haben, als 'Utmān ermordet wurde (Ibn Sa'd 20, 11 ff.); zu seinem Holzschwert ib. 20, $15 \mathrm{f}$.

126 Vgl. Ibn 'Abdalbarr 1960: 77, 6, wo Sa'd b. Abī Waqqāṣ als „Sa'd b. Mālik“ auftritt und noch vier weitere „Neutrale“ aus der nächsten Generation genannt werden. $\mathrm{Zu}$ diesen „Mu'taziliten“ vgl. van Ess 1972: 121 ff. Das K. al-Fitan des Nu'aim b. Ḥammād enthält übrigens von 'Abdallāh b. 'Umar ein Ḥadìt, aus dem hervorgeht, daß im Falle einer bewaffneten Auseinandersetzung unter Muslimen beide Kontrahenten in die Hölle kommen (Nu'aim 1991: 1: 165 nr. 425); ähnlich kurz darauf (nr. 432) auch ein Ausspruch des Sa'd b. Abī Waqqāṣ (nach Ibn Sīrinn), wonach anders als im Ğihād man im Bürgerkrieg immer vor der unentscheidbaren Frage steht, ob man den Gegner als mu'min oder als kāfir einordnen soll (vgl. dazu die Übersetzung bei Aguadé 1979: 73 f., der darauf hinweist, daß das Ḥadīt des Ibn 'Umar sich auch bei Ḥākim an-Naisābūrī 1915-1923: 4: 471, 1f. findet). Daß die mu'tazilūn allgemein so dachten, notiert Ğa 'far b. Ḥarb in seinem K. Ușūl an-nihal (in: van Ess 1971: ar. Text 16, 15 ff. mit dem entsprechenden Ḥadīt). Für Ibn 'Umar vgl. auch die Stelle bei Ibn Ḥanbal 1946-1975: 8: 82f. nr. 5708 (wo der Schluß dann allerdings abweicht).

127 Vgl. hierzu wie zum Folgenden van Ess Unfertige Studien, nr. 1: 1394 mit Anm. 21-22.

128 Pseudo-Ibn Qutaiba 1967: 1: 182, pu. ff.

129 van Ess 2016: 1394, Anm. 21. Wir müßten ihn gegebenenfalls unter die falschen mu'ammarūn aufnehmen (vgl. Juynboll 1991), und die in den späteren Quellen gegebenen biographischen Daten wären nachträglich errechnet. 
Offenkundig wird der chronologische Querstand in einem weiteren Text, der mit der Schlacht auf der Harra zu tun hat. Er hat wiederum die Form eines Prophetenwortes und läßt sich darum nur als Weissagung verstehen. Muhammad unterhält sich mit Abū Darr al-Ġifārī, der bereits i. J. 32/652-3 gestorben war, und fragt ihn: „Wie wirst du dich verhalten, wenn du siehst, wie die Ölsteine im Blute ertrinken? Halte durch, bis du dich mit Leuten deiner Gesinnung zusammentun kannst!“130 Die „Ölsteine“ lagen auf der Harra, dort wo in dem felsigen Boden schwarze Lavablöcke zum Vorschein kamen, die wie von Öl bedeckt glänzten. Der alidische Prätendent an-Nafs az-zakīya, der i. J. 145/763 gegen den Abbasiden al-Manșūr sein Glück versuchte, kam dort zu Tode. Aber er ist hier wohl nicht gemeint; denn es gibt eine ausführlichere Version dieses Hadīt, die Ibn Māğa in seinen Sunan bewahrt hat. ${ }^{131}$ Dort beginnt der Prophet mit der Frage: „Wie wirst du dich verhalten, Abū Darr, wenn ein(e solche Art des) Sterben(s) die Menschen ereilt, daß ein Haus (in dem dies vor sich geht, nur noch) von dem Hausknecht in Ordnung gehalten wird (hattā yuqauwamu l-bait bil-wașîf)?“132 Abū Darr antwortet darauf mit jener Schicksalsergebenheit, die

130 Vgl. van Ess Unfertige Studie 4: 930-931.

131 Ibn Māğa 1952: 1308 (Fitan 10 nr. 3958)=Ibn Māğa 2000: 571 f. nr. 4093.

132 Ich weiche mit dieser Übersetzung von der üblichen Interpretation ab. Schon Ibn Māğa hat, wie eine Glosse im Text zeigt, bait metaphorisch verstehen wollen: ya'nī al-qabr. Zamahšarī hat dies aufgenommen: Die Gräber werden aus Platzmangel so teuer, daß man sie um den Preis eines Haussklaven kaufen muß (Zamahšarī 1945: 1: 124, 8 ff.) Auch Ibn al-Atīr versteht die Stelle ähnlich (Ibn al-Atīr 1963: 5: 191, 14 ff.; vgl. Lane 1863-1893: 280b). Aber bait heißt normalerweise nicht qabr (im Sinne von „letzte Ruhestätte“). Die metaphorische Bedeutung wird in den Wörterbüchern nur durch einen Vers des Labīd dokumentiert; dann folgt als zweiter Beleg gleich das obige Ḥadīt (so im Lisān al-'Arab= Ibn Manẓūr 1955: 2: 15, 5 ff. s. v., wo im Zusammenhang damit auch Ibn al-Atīr zitiert wird). Bei Labīd ist der metaphorische Gebrauch offenkundig und erklärt sich aus dem Kontext; in dem Hadīt dagegen ist dies nicht der Fall. Der moderne Herausgeber des Ibn Māğa hat darum auch ohne diesen Schlenker auszukommen versucht (trotz der Glosse im Text): „Häuser werden bei dem Massensterben so billig sein wie ein kleiner Sklave, weil es keine Menschen mehr gibt, die darin wohnen wollen“ (Ibn Māğa 1952: 1308, Anm. zur Stelle). Aber auch das leuchtet kaum ein. Es ist davon beeinflußt, daß sowohl Zamahšarī als auch Ibn al-Atīr unter dem Druck einer Tradition stehen, die mit der Formulierung yubtā'u bil-wașîf arbeitèt. In der „Urfassung“ aber stand offenbar yakūnu bil-wașîf (so noch bei Ibn al-Atīr, aber auch bei Ḥākim an-Naisābūrī 1915-1923: 4: 423, ult.); yuqauwamu bei Ibn Māğa ist isoliert. In beiden Fällen ist das bi vor wașîf kein bi pretii, sondern bezeichnet das logische Subjekt des Satzes. Gedacht ist wohl an den Tod des Kalifen 'Utmān. Er wurde in seinem eigenen Hause ermordet und seine Frau Nā'ila so schwer verwundet, daß sie das Haus nicht mehr „regieren“ konnte. Späteren Interpreten (zu denen auch Ibn Māğa schon gehörte) lag eine solche Assoziation fern. Meine Übersetzung bleibt jedoch weiter zu überprüfen. Dabei wäre auch Gilliot 2013: 327 zu vergleichen; er übersetzt mit „Das (letzte) Haus kann nur mit einem Sklaven bezahlt werden“ und macht damit aus dem Interpretamentum yubtā'u einen Textbestandteil. An eine metaphorische Bedeutung von bait glaubt auch er nicht. - Maut, das 
ihm als einem späteren gesellschaftlichen Außenseiter wohl anstand: „(Ich werde mich so verhalten), wie Gott und Sein Gesandter es für mich bestimmen.“133 - „Halte durch! (Aber) wie wirst du dich verhalten, wenn ein(e bisher nicht erlebte Art des) Hungern(s) die Menschen ereilt, so daß du in deine Moschee gehst und dann keine Kraft mehr hast, wieder ins Bett zu kriechen, oder wenn du (noch) nicht (einmal) aus deinem Bett aufstehen kannst, um in die Moschee zu gehen?“134 - „Gott und Sein Gesandter wissen das am besten.“135 _ „Übe dich in Zurückhaltung ('iffa)! ${ }^{136}$ (Aber) wie wirst du dich verhalten, wenn ein(e neue Art des) Töten(s) die Menschen ereilt, so daß die 'Ölsteine’ im Blute ertrinken?“ - „So, wie Gott und Sein Gesandter es mir bestimmen.“ - „Schließ dich einem an, der so denkt wie du!“ - „O Gesandter Gottes, sollte ich nicht mein Schwert ziehen und auf diejenigen, die (eben) das tun, dreinschlagen?“ „(Nein. Denn) dann würdest du dich mit dem (normalen) Volk (al-qaum) gemein machen. Du solltest vielmehr nach Hause gehen.“ - „Aber wenn nun, o Gesandter Gottes, jemand in mein Haus eindringt?“ - „Wenn du fürchtest, daß das Funkeln (seines) Schwertes dich blendet, so zieh dir den Zipfel deines Obergewandes über das Gesicht! Denn (wenn er dich dann totschlägt, so) nimmt er seine und deine Schuld auf sich und kommt in die Hölle.“

Wir haben hier anscheinend einen Komposittext vor uns. Wenn dort zu Anfang Abū Darr der Rezipient von Muhammads pessimistischer Vorhersage ist, so hat dies nur Sinn, wenn das Ereignis, an das der Erzähler denkt, von Abū Darr noch wahrgenommen werden konnte. Dieser hat in der Tat vor seinem Tode die Ermordung des dritten Kalifen (also die „erste fitna“) noch erlebt allerdings nicht in Medina; denn er war von 'Utmān nach Rabada verbannt worden. Der Erzähler kann ihm darum Worte in den Mund legen, die nach seiner eigenen Auffassung in einer fitna angemessen sind. Für das Zitat aus Sure 5:29 war Abū Darr freilich nicht der rechte Mann; er ist ja an der fitna selber nicht beteiligt gewesen. Er hatte nie eine Schuld auf sich genommen, die er hätte weitergeben können. Darum kommt dieses Zitat auch erst ganz zum Schluß.

\footnotetext{
„Sterben“, steht wie die entsprechenden Wörter in den folgenden Sätzen (ǧŭ und qatl) nach einem wa- im Akkusativ; es handelt sich um ein wāw al-ma ìya (vgl. Reckendorf 1921: 325 ff. $\S 165.11)$.

133 Der Text bringt dazu die Variante: „Gott und Sein Gesandter wissen das am besten“, also: „Wer weiß? Gott wird es bestimmen, und nur der Prophet kann es voraussehen“.

134 In beiden Fällen ist wohl an das Morgengebet gedacht, zu dem man früh aufstehen muß. 135 Auch hier bringt der Text wieder als Variante: „So, wie Gott und Sein Gesandter es für mich bestimmen werden“ Der Erzähler hat also vielleicht auf Wechsel im Ausdruck geachtet; aber die Reihenfolge der beiden Formulierungen war den Überlieferern nicht klar.

136 Das Wort 'iffa hat ein breites Bedeutungsspektrum. Gemeint sein kann auch „Sittsamkeit, Rechtschaffenheit“.
} 
Andere Ereignisse werden assoziiert, und der szenische Hintergrund wechselt. Ohnehin gab es Kreise, in denen bezweifelt wurde, ob sich die Revolte gegen 'Utmān schon als fitna bezeichnen lasse. ${ }^{137}$ So kommen dann die „Ölsteine“ ins Gespräch und mit ihnen auch das Koranzitat; ein anderer Erzähler hat also die Geschichte fortgesetzt. Vorher ist von einer Hungersnot die Rede, die anscheinend ebenfalls in Medina auftrat; vielleicht ist an die Wirtschaftsblockade des Hiǧāz gedacht, mit der Haǧğāğ den Gegenkalifen 'Abdallāh b. az-Zubair in die Knie zwingen wollte. ${ }^{138}$ Der Text ist also nicht nur fiktiv, sondern auch im Laufe der Zeit gewachsen. ${ }^{139}$ Die Prophezeiung erhielt damit größeres Gewicht. Zugleich jedoch verlor sie an Wahrscheinlichkeit; es war nicht leicht einzusehen, warum der Prophet sich vor Abū Darr zu den Ölsteinen geäußert haben sollte, deren Wichtigkeit während einer fitna dieser gar nicht mehr erlebt haben konnte. Kritische Sammler wie Buhārī oder Muslim enthalten diesen Text in der Tat nicht. ${ }^{140}$

Aber warum hat die Schlacht an den Ölsteinen für das „kollektive Gedächtnis“ überhaupt eine solche Rolle gespielt? Doch wohl, weil aus der Sicht der Hadītüberlieferer da die eigenen Leute die Verlierer gewesen waren; diese hätten eigentlich wissen sollen, daß es besser war, wie Abel in den Tod zu gehen. Die Syrer hatten ihnen gezeigt, daß Frömmigkeit nicht ausreichte, um mit Erfolg das Schwert zu führen. So könnte es dazu gekommen sein, daß man einem der medinensischen Frommen, der, wie man meinte, die Gewalt der Syrer hatte ertragen müssen, nämlich $A b \bar{u}$ Sa'īd al-Hुudrī, ein Hadīt in den Mund legte, wonach eine weitere Schar von Frommen, die den Koran im Übermaß rezitierten und in der Konsequenz ihre Gemeinschaft mit den Muslimen aufkündigten, die Hāriǧiten nämlich, darüber zu Ungläubigen wurden, welche mit Recht die Hölle verdienten und deswegen bekämpft werden mußten - allerdings im Irak und nicht in Medina. Aber wir wollen diese Hypothese ${ }^{141}$ jetzt nicht weiter vertiefen.

Vielmehr ist es an der Zeit, nach der noch etwas aleatorischen Spurensuche wieder auf unsere ursprüngliche Fragestellung zurückzukommen. Der

137 Juynboll hat dieser Frage einen eigenen Artikel gewidmet (Juynboll 1973). Er kommt zu dem vermutlich etwas zu skeptischen - Ergebnis, daß man erst nach dem Tode des Muhammad b. Sīrīn (110/728) die späteren fitan bis auf die Ermordung 'Utmāns zurückgeführt habe (S. 158f.).

138 Vgl. van Ess Unfertige Studie 1: 1394.

139 Das geht auch aus der Version im Mustadrak des Ḥākim an-Naisābūrī hervor. Sie ist ähnlich umfangreich wie die des Ibn Māğa, beginnt aber mit dem Hungern, und die „Ölsteine“ sind verschrieben bzw. verdruckt: (aṣhāb) ar-r.t.b statt az-zait (Ḥākim an-Naisābūrī 1915-1923: 4: 423, $1 \mathrm{ff}$.).

140 Im Isnād der ausführlicheren Fassung taucht Ḥammād b. Zaid auf (gest. 179/795), dem wir oben in Anm. 59 begegneten.

141 Vgl. van Ess Unfertige Studie 1: 1393 ff. 
Ausspruch Abels (Sure 5:29) hat den frühislamischen Erzählern lange in den Ohren geklungen. Aber seine theologische Problematik ist ihnen erst allmählich bewußt geworden. Man projizierte die Worte auf Erfahrungen, welche die Muslime mit ihrem eigenen Bruderzwist gemacht hatten. Im Wunschbild hätten sie Einigkeit zeigen und innerhalb ihrer Grenzen Frieden halten sollen; aber dieser Friede war immer wieder gebrochen worden. Krieg war jedoch nur sinnvoll und vielleicht sogar geboten - im Falle des ǧihäd; dann richtete er sich gegen Ungläubige. In einem Krieg innerhalb der Gemeinde dagegen fiel man, wenn man sich an ihm beteiligte, in Schuld; man sprach da auch nicht von Krieg (harb), sondern von einer Anfechtung oder Versuchung (fitna). ${ }^{142}$ Der Schuld entging man, indem man sich aus dem Ort des Geschehens zurückzog; man kannte aus dem Kreis der Prophetengenossen Personen, die sich ferngehalten hatten (die sog. mu'tazilūn). Aber das war nicht jedem und nicht überall möglich. In einem solchen Fall empfahl es sich, aus dem Geschehen auszusteigen und sich fortan passiv zu verhalten. Wenn man selber zum Opfer wurde (und schlimmstenfalls sein Leben verlor), übertrug man die Schuld, die man durch seine anfängliche Teilnahme am Geschehen auf sich geladen hatte, auf den Gegner. Dieser war durch sein Verhalten zum Mörder geworden, und wenn er deswegen ewige Verdammnis verdiente, kam er nun zwiefach belastet in die Hölle. Selber konnte man sicher sein, ins Paradies einzugehen, wenn auch vielleicht nicht ganz so schnell wie ein muğāhid.

Das hörte man aus Sure 5:29 heraus, und man assoziierte dabei, daß auch Abel eine Schuld auf sich geladen hatte, die er dann aber bei seinem Tode an Kain weitergab. In einer fitna solle man sich verhalten „wie der Bessere unter den beiden Söhnen Adams“, so hatte angeblich Habbāb b. al-Aratt zu seinem Sohn gesagt; ${ }^{143}$ er war dann von den Hुāriǧiten ermordet worden. ${ }^{144}$ Dirār b. 'Amr hat das Dictum als Hadīt gekannt. ${ }^{145}$ Nur daß man bei dieser weitergereichten Schuld nicht an diejenigen Sünden dachte, die jeder Mensch auf sich lädt und für die er beim Gericht auch geradestehen muß. Die Hadīte lassen vielmehr anklingen, daß nur eine einzige Sünde gemeint war: der Mord. Die gewaltsame Tötung eines

142 Allgemein zu diesem Begriff vgl. Tayob 1993, wo aber Sure 5:29 verständlicherweise nicht berücksichtigt ist.

143 Quelle ist wieder das K. al-Fitan des Nu'aim b. Ḥammād (vgl. Aguadé 1979: 77).

144 Vgl. van Ess Kleine Schriften III 1504, Anm. 16.

145 S. o. S. 459. Vgl. Abū Dāwūd 2000: 2: 708 nr. 4259 (Fitan 2), wo das „Sei wie die beiden Söhne Adams“ direkt mit Sure 5:29 verbunden wird. Ähnlich auch Ibn Ḥanbal 1946-1975: 8: 124 nr. 5754: „Was hindert einen von euch daran, sich wie die beiden Söhne Adams zu verhalten, wenn jemand kommt, der ihn töten will? Der Mörder kommt in die Hölle, der Getötete ins Paradies.“ Dort überliefert dies 'Abdallāh b. 'Umar, als er einen (abgeschlagenen) Kopf (auf einer Stange) sieht. 
Glaubensbruders (ah) wurde als Aufkündigung der Glaubensgemeinschaft (ğamáa $a$ ) verstanden; denn der Mörder verfährt mit dem „Bruder“ wie mit einem Ungläubigen, dessen Tötung im ğihād ja erlaubt war. Im Bruderkrieg gilt das nicht, und wer hier darauf verzichtet, sich einem Feind zu widersetzen, bleibt ein Mitglied der Glaubensgemeinschaft. ${ }^{146}$ Das ist wohl auch der Grund, warum ihm dann das Paradies zuteil wird. Man dachte in der Frühzeit noch weitgehend kommunalistisch; ein Muslim geht in das Paradies ein nicht, weil er ohne jede Sünde wäre oder bloß läßliche Sünden begangen hat, sondern weil er im rechten Glauben ist. Erst in Bașra vollzog sich, wohl unter dem Einfluß des Ḥasan al-Bașrīi, die individualistische Wende. Jeder Muslim war nun auf sich selbst gestellt und für sich selber verantwortlich; er mußte darum auch dauernd sein Gewissen befragen, ob er nicht in Sünde fällt oder in Sünde fallen könnte. Damit gewann Abels Ausspruch ein anderes Gesicht; in der Diskussion, die man jetzt zu führen begann, verlor das Wort dann schnell an Schlagkraft.

30: Da legte ihm seine Seele nahe, seinen Bruder zu töten. Und so tötete er ihn. Und er wurde einer von denen, die den Schaden haben.

Vers 30 bestätigt, was man nach Abels Rede schon ahnte. Die damaligen Hörer kannten den Ausgang der Geschichte und erfuhren an dieser Stelle nichts Neues. Erst die moderne Exegese zerbricht sich den Kopf darüber, ob Abel eine Vorhersage ausgesprochen hatte oder einen Fluch. Kain, dem in Vers 29 das Höllenfeuer angedroht wurde, ist jetzt „einer von denen, die den Schaden haben“; ${ }^{147} \mathrm{er}$ ist „selber schuld.“ Țabarī kann sich kurz fassen. Er wiederholt, was er vorher schon einmal referiert hatte: daß nämlich Kain befürchtete, Abel werde herumziehen und sich seines Opfers (und der besseren Beziehungen zu Gott) rühmen. ${ }^{148}$ Wir stoßen auch auf eine elaboriertere Fassung der Geschichte von den

146 Auf diese Situation nimmt ein Ḥadīt bei Muslim b. al-Ḥağǧăğ 1955-1956: 79 (İmān 111) Bezug: „Wenn jemand seinen Glaubensbruder als Ungläubigen bezeichnet, so geht (immer) einer von beiden mit einer Sünde davon." Also: Eigentlich gehört sich das nicht. Aber wenn nun einmal ein Muslim einen andern Muslim wie einen Heiden behandelt oder ihn als solchen bezeichnet, so kommt es darauf an, ob er recht hat; sonst fällt er selber in Schuld. Anstatt $b \bar{a}^{\prime} a$ $b i-i t m$ steht hier nur $b \bar{a}^{\prime} a$ bihā; bei dem Suffix ist wohl ma șiya subintelligiert. Tradent ist bezeichnenderweise wieder 'Abdallāh b. 'Umar.

147 Die Redewendung begegnet im Koran sehr häufig (vgl. die Konkordanz s. v. hāsirūn; auch Khoury 1990-2001: 1: 214 zu Sure 2:27). Das Wort hasira „Bankrott machen“ gehört zu jenen Business-Begriffen, die Charles Cutler Torrey in seinem The Commercial-Theological Terms in the Koran zusammengestellt hat (Torrey 1892: 30-32). Es handelt sich bei dieser (relativ kurzen) Studie im übrigen um die Doktorarbeit, die Torrey unter Th. Nöldeke in Straßburg anfertigte. Er entdeckte von seiner amerikanisch-calvinistischen Lebenswelt her in dem Eleven der „Kauffrau“ Hadīğa offenbar einen Geistesverwandten.

148 Ṭabarī 1954-: 10: 222f. nr. 11750; vgl. nr. 11,706 (oben Anm. 8). 
Ehen überkreuz, in der ausdrücklich gesagt wird, daß später in dieser Art nur die bint 'amm-Ehe noch erlaubt war. ${ }^{149}$ Wir haben die entsprechenden Berichte oben nach Tabarīs Ta'rīh zitiert ${ }^{150}$; aber erst hier, in einem exegetischen Text, wird klar, daß Adams Verfahren nicht mehr als eine Notlösung sein konnte. Namen kommen jetzt nicht mehr vor; das war eine Aufgabe der Historiker. Stattdessen tritt eine Rahmenerzählung hinzu, in der Sa ${ }^{\prime} \bar{l} d$ b. Ğubair ${ }^{151}$ beim Hağğ ${ }^{152}$ jemanden darüber informiert, daß der Widder, der damals geopfert wurde, von Gott in Gewahrsam gehalten worden war (lam yazal maḩbūsan 'inda llāh), bis er bei Abrahams Opfer wieder in Aktion trat, als dessen Sohn (Isaak oder Ismael) durch ihn losgekauft wurde. ${ }^{153}$ Erst im Zusammenhang dieses Verses wird dann auch die Frage aufgeworfen, wie Kain überhaupt wissen konnte, was man zu tun hat, wenn man jemanden umbringen will; wir haben sie oben bereits behandelt. ${ }^{154}$ Aber Tabarī hält sich in seiner Exegese streng an die Ordnung: Erst muß gesagt sein, daß der Mord tatsächlich geschehen war (Vers 30); dann kann man darüber nachdenken, wie das vor sich ging.

Zuvor allerdings war er kurz auf ein sprachliches Problem eingegangen: Wie ist țauwa'at lahū nafsuhū zu Beginn des Verses zu verstehen? Auch Paret ist sich

149 Ṭabarī 1954-: 223 nr. 11,751.

150 S. 450; vgl. Anm. 14.

151 Ein kūfischer Religionsgelehrter, der wegen seiner Teilnahme am Aufstand des Ibn al-Aš‘at von Ḥaǧğăğ i. J. 94/711 oder 95/712 hingerichtet wurde. Zu ihm EI²: 12: 697 f. (H. Motzki); auch TG: Index s. n. und Gilliot 2013: 318.

152 Er war verschleiert (mutaqanna) und gerade dabei, die Kiesel zu werfen, mit denen man „den Satan steinigte.“ Die Szene spielt also während seines Mekka-Aufenthaltes, als er aus dem Irak geflohen und noch nicht von Hูālid al-Qasrī an Ḥaǧğāğ ausgeliefert worden war.

153 Was ja nach islamischer Vorstellung ebenfalls in Mekka geschah. Der Widder hatte, wie man sich dachte, solange im Paradies geweidet (Ta'labī 2006: 59). Die Geschichte steht in derselben Form auch in Ṭabarīs Ta'rīh (Ṭabarī 1879-1901: 1: 139, 10 ff. / übs Ṭabarī 1989: 309f.); dort wird später noch einmal auf sie angespielt (1: 307, 14 ff. / übs. Ṭabarī 1991: 95). Im Isnād begegnet der Mekkaner Ibn Ğuraiğ (gest. 150/767); er hat vermutlich für die Verbreitung gesorgt. Als Gesprächspartner des Sa'īd b. Ğubair fungiert ein gewisser 'Abdallāh b. 'Utmān b. Hutaim, über den wir kaum etwas wissen (vgl. zu ihm Dahabī 1963-1965: 2: 459 f. nr. 4442 und Ibn Hağar 1907-1909: 5: 314 f. nr. 536). Die beiden Widder zu einem einzigen zu machen, war natürlich ein exegetisches Husarenstück. Es blieb auf immer mit dem Namen des Sa`ìd b. Ğubair verbunden (vgl. etwa Ta labī 2006: 127). Dabei waren die Exegeten sich gar nicht einig darüber, welche Species von Abel eines Opfers gewürdigt worden war: ein Zicklein ('anāq, vgl. nr. 11,718), ein Lamm (hamal, nr. 11,713) oder sogar eine Kuh (obgleich sie nicht in die nomadische Fauna hineinpaßte; vgl. Țabarī 1879-1901: 1: 141, 4 / übs 1989: 311). Meist sprach man einfach von einem Schaf; Abel wird als șāhib aš-šāt bezeichnet (Ṭabarī 1954-: 10: nr. 11,707 und 11,710-11).

154 Vgl. Țabarī 1954-: 10: 221 f. nr. 11,746-49 mit oben S. 459, Anm. 43 (wo nr. 11,747-8 zitiert werden). 
da nicht ganz sicher. ${ }^{155}$ Aber wir lassen das hier beiseite und konzentrieren uns auf das Wort nafs. Es wird im Koran in verschiedener Bedeutung gebraucht. Meist ist „Person“ gemeint, hier dagegen die „Seele“, u. z. derjenige Teil von ihr, der in Sure 12:53 als ammāra bis-sū' bezeichnet wird (,gebieterisch nach dem Bösen verlangend“, wie Paret übersetzt), ${ }^{156}$ also die „Triebseele“ in der Sprache der späteren Asketen und Mystiker. In dem Bruderpaar Kain-Abel fallen die beiden Seelenteile (oder der böse und der gute „Trieb“) paradigmatisch auseinander. ${ }^{157}$

Der folgende Koranvers (5:31) berichtet davon, wie Kain lernte, eine Leiche aus dem Wege zu schaffen. Bis heute wird die Findigkeit eines Mörders dadurch ja auf eine harte Probe gestellt. Nur im Krieg löst sich das Problem von allein; man läßt nach einer Schlacht die Toten einfach liegen. Unter zivilisierten Umständen reichte das nicht aus; die Leiche wurde zur Belastung. Wie der Koran erzählt, lernte Kain durch Naturbeobachtung; er sah, wie ein Rabe den Boden aufscharrte, um einen andern Raben zu begraben. Das ist aus arabischer Sicht eine $a w \bar{a}$ 'il-Geschichte: ${ }^{158}$ Kain ist der erste, der weiß, wie man in einem solchen Fall vorzugehen hat - ebenso wie er der erste war, der wußte (bzw. lernte), wie man einen Menschen umbringt. Allerdings ist der Koran nicht das erste Zeugnis dafür, daß man sich über der Sache den Kopf zerbrach; die Geschichte stammt vielmehr aus einem jüdischen Midrasch. ${ }^{159}$

Auffällig ist daran aus heutiger Sicht nur, daß Kain nicht auf den Gedanken kam, die Leiche zu verbrennen. Ein Akt der Verbrennung hatte ja bereits bei dem Opferwettstreit im Mittelpunkt gestanden. Beide Opfer waren als Brandopfer konzipiert, „Holokaust“ auf griechisch (wörtl.: etwas, das „zur Gänze verbrannt“ wird), 'olāh auf hebräisch (wörtl.: etwas, das „(zum Himmel) aufsteigt“, wohl in

155 Er übersetzt țauwa'a mit „nahelegen“, versieht dies aber mit einem Fragezeichen. Khoury hat: „sie machte ihn willig“, Arberry: „prompted him“, Cuypers, Festin 146: „le disposa à tuer“ Sidersky kommt ganz ohne die Seele aus und sagt: „sa passion le poussa à tuer“ (Sidersky 1933: 17).

156 In Sure 12:53 drückt Josef sich so aus. Er will damit erklären, warum er der Verführung durch die Frau des Potiphar beinahe erlegen wäre.

157 Von den Seelenteilen und dem Gegensatz zwischen nafs und qalb habe ich in meiner Doktorarbeit gehandelt (van Ess 1961: 31 ff.). Jedoch hatte ich für den Koran damals nur die Dissertation von S. Talaat, Die Seelenlehre des Korans mit besonderer Berücksichtigung der Terminologie (Talaat 1929) zur Verfügung. Ich überschaue nicht, wieweit in der Zwischenzeit maßgebliche Untersuchungen, auch im Hinblick auf die Seelenlehre Platons und ihren Einfluß auf die christliche Theologie und Mystik des Vorderen Orients, hinzugekommen sind. Der Artikel Nafs in $\mathrm{EI}^{2}:$ 7: 880a $<\mathrm{EI}^{1}$ : 3: 893-897 (E.E. Calverley) ist gut, aber veraltet.

158 Für Ibn Ishāq war Abel auwal qatīl min banī Ādam (Ṭabarī 1954-: 10: 228, 3).

159 Tanhūmā berēšìt; vgl. Speyer 1931: 86 f. und Cuypers 2009: 200, Anm. 10. Auch Sidersky 1933: 18. 
Gestalt des Rauches). ${ }^{160}$ Aber die muslimischen Exegeten gingen nicht davon aus, daß die beiden Brüder das Feuer selber entzündet hatten. Vielmehr fiel Feuer vom Himmel, das Abels Opfertier verzehrte; ${ }^{161}$ bei Kains Ackerfrüchten passierte gar nichts. ${ }^{162}$ So erkannten Kain und Abel dann auch, wer vor dem Auge Gottes Gnade gefunden hatte - nicht etwa daran, daß von Abels Altar der Rauch zum Himmel aufstieg, während er bei Kains Opfer am Boden blieb. Dieses letztere Kennzeichen kommt erst in frühchristlichen bildlichen Darstellungen zur Geltung, und zwar in Rom; ${ }^{163}$ im Buche Genesis war von Rauch noch keine Rede gewesen. Kain hätte also nicht nur lernen müssen, wie man jemanden begräbt, sondern auch, wie man Feuer macht. ${ }^{164}$ Die Geschichte mit dem Raben erhielt von daher ihren Sinn. Daß es in anderen Kulturen üblich war, Leichen zu verbrennen (oder sie auf Türmen der Verwesung auszusetzen, wie in Iran), wußte man in frühislamischer Zeit vielleicht; aber man empfand es als widernatürlich. ${ }^{165}$

160 Zur Organisation des Brandopfers vgl. 3. Buch Mose (=Leviticus) 1:6-17. Im Tempel wurde es normalerweise am Morgen vollzogen (vgl. 2. Kg. 16:15 und Ez. 46:12-15).

161 Dachte man an einen Blitz? Vgl. Țabarī 1879-1901: 1: 138, 12 / übs Țabarī 1989: 308, Ṭabarī 1879-1901: 1: 141, 4f. / übs Ṭabarī 1989: 311 und Ṭabarī 1879-1901: 1: 143, 6 / übs Ṭabarī 1989: 313 in jeweils anderem Erzählzusammenhang; auch Ta'labī 2006: 58.

162 Später meinte man, daß auch bei einem Tieropfer das Feuer nur dann in Aktion trete, wenn das Opfer von Gott angenommen werde; sonst werde das Fleisch von wilden Tieren gefressen (Ta'labī 2006: 58).

163 In den Mosaiken von San Paolo fuori le mura. Die Vorstellung hält sich dann in Europa durch die Jahrhunderte. Zwar findet sich auch der „Lichtstrahl“ anfangs noch (also wohl das Feuer, das vom Himmel fällt); aber er steht in haggadischer Tradition (Lexikon der christlichen Ikonographie I 7b).

164 Mitgespielt hat natürlich auch, daß man die Brandopfer längst aus den Augen verloren hatte; sie waren in frühislamischer Zeit schon seit Jahrhunderten nicht mehr üblich. Bei den Juden konnten sie spätestens seit der Zerstörung des Tempels i. J. 70 nicht mehr praktiziert werden, und die Christen vollzogen das Opfer nur noch in symbolischer Weise, im „Meßopfer“, der Eucharistie. Die Muslime opferten zwar weiterhin Tiere; aber sie verbrannten sie nicht, sondern gingen mit dem Fleisch auf vernünftigere Weise um, indem sie es zum Verzehr freigaben. Allerdings aßen sie es nicht selber, sondern verteilten es unter Bedürftige oder Angehörige. Man denke an die gigantischen Kühlhäuser im heutigen Mekka.

165 Interessanterweise haben manche Muslime gemeint, daß Kain später einen Feuertempel gebaut habe (Ta'labī 2006: 62). Man empfand das Feuer vermutlich als zerstörerisch; der Mensch mußte erst lernen, es zu zähmen. Nützlich war es darum anfangs nur, wenn es vom Himmel kam - wie der Regen. Es ist in diesem Zusammenhang ganz lehrreich, eine Studie des französischen Philosophen Gaston Bachelard (1883-1962) zu vergleichen: La psychanalyse du feu (Bachelard 1937; dt. Psychoanalyse des Feuers, München 1985). Er versteht das Feuer in erster Linie als wärmend und lebenspendend; darum zieht er die Sexualität zum Vergleich heran. Das ist europäisch gedacht; viele seiner Belege stammen aus der deutschen Romantik. Im Orient, unter anderen klimatischen Verhältnissen, fürchtete man das Feuer. Daß man Tote 
Wir belassen es bei diesen wenigen Bemerkungen und überspringen ansonsten den Vers. Erwähnenswert ist nur noch der Schluß, in dem es heißt, daß Kain „sich zu den Bereuenden gesellte“ (aṣbaḥa min an-nādimīn). Schon laut Gen. 4:13 hatte er nach der Tat zu Gott gesagt: „Meine Sünde ist größer, denn daß sie mir vergeben werden möge. “ Das ist hier verstärkt und bringt Kain wieder in die Nähe seines Vaters. Auch von Adam heißt es nämlich im Koran, daß er seinen „Fall“ bereute; Gott habe sich ihm hernach in Gnade wieder zugewandt. ${ }^{166}$ Das ist typisch islamisch. Der Koran vertritt eine optimistische Sicht des Menschen; niemand ist grundsätzlich böse, und es gibt keine „Erbsünde.“ Allerdings haben schon jüdische und sogar frühchristliche Kreise mit Theologoumena experimentiert, in denen von einer Bekehrung Kains und Adams die Rede ist. ${ }^{167}$ Aber man darf den Unterschied im Ausdruck nicht übersehen. Bei Adam wird tāba gebraucht, im reziproken Sinne; ${ }^{168}$ er ist ein Prophet, der in Gottes Plan vorgesehen war. Bei Kain dagegen steht nadima, und Paret übersetzt betont abschwächend: „er empfand Bedauern (und Ärger über das, was geschehen und nicht mehr zu ändern war).“ Aber auch das ist für unsere Fragestellung nicht von essentieller Bedeutung und führt im Falle Kains geradezu von ihr ab. Darum wenden wir uns dem letzten, verhältnismäßig langen Vers zu, allerdings auch da nur dessen Anfang, wo Kains Untat noch einmal aus juristischer Sicht beleuchtet wird.

32: Aus diesem Grund haben wir den Kindern Israels vorgeschrieben, daß, wenn einer jemanden tötet (und zwar) nicht (etwa zur Rache) für jemanden (anders) oder (zur Strafe für) Unheil (das er) auf der Erde (angerichtet hat), es so sein soll, als ob er die Menschen alle getötet hätte .....

Von Kain ist namentlich nicht mehr die Rede. Aber er ist als Paradigma weiter anwesend. Er hat den Mord in die Welt gebracht, und wenn von nun an jemand unrechtmäßig getötet wird, so ist es, als ob die Menschheit insgesamt getötet

verbrennt, ist ja auch bei uns eine ganz junge Erscheinung, die wir vor allem als Notmaßnahme rechtfertigen, etwa bei der Massenverbrennung auf Holzstößen nach dem Bombardement der Stadt Dresden. Mit Bezug auf Auschwitz wird es als Kulturbruch empfunden. Daß dabei das Wort „Holokaust“ in Gebrauch gekommen ist, wirkt mißverständlich; ein „Brandopfer“ hatte ja im Tempel dem Lobe Gottes gedient. Die schiefe Metapher geht auf einen amerikanischen Filmemacher zurück. In Israel hat man darum einen neuen Begriff ins Spiel gebracht, die „Schoa“.

166 Sure 2:37 und 20:122. Das Verb tāba, eigentlich „umkehren“ (vgl. hebr. šūb), wird im Arabischen reziprok gebraucht, als „Buße tun“ vonseiten Adams und „sich wieder zuwenden“ vonseiten Gottes.

167 Für Kain vgl. Speyer 1931: 87, für Adam ib. 73 ff. Zu Kain wäre Gen. 9:13 zu vergleichen; Cuypers verweist dazu auch auf die griechische Version in der Septuaginta (Cuypers 2009: 200). 168 Bei Adam im Sinne von „umkehren“, bei Gott im Sinne von „sich wieder zuwenden“. 
werde. ${ }^{169}$ Darum war, so sagt dieser Vers, der Mörder im jüdischen Gesetz verfemt; so stehe es in der hebräischen Bibel, die Gott auf Mose herabgesandt hatte. In der Tat hat schon Abraham Geiger nachweisen können, daß es für diese Aussage eine jüdische Vorlage gibt, in Mišnā Sanhedrīn. ${ }^{170}$ Aber die Formulierung nimmt eher jene Perspektive voraus, unter der man später in der šarī $a$ den Mord in den Blick nahm: als gewaltsame Tötung, die weder durch die talio gerechtfertigt ist noch als obrigkeitliche Hinrichtung aufgrund eines Verbrechens erfolgt. ${ }^{171}$ Das ist im Hadīt aufgenommen und weiter präzisiert worden: „Wenn ein Muslim bezeugt, daß es keinen Gott gibt außer dem Gott und daß ich der Gesandte Gottes bin, ${ }^{172}$ so ist es nicht mehr erlaubt, dessen Blut (zu vergießen) - außer in drei Fällen: Leben um Leben (an-nafs bin-nafs, also bei Mord), bei Ehebruch ${ }^{173}$ und wenn jemand ... die Gesamtgemeinde verläßt“174 Da ist also als dritte Ausnahme jene Aufkündigung der Glaubensgemeinschaft hinzugekommen, als die man auch die Teilnahme am Bürgerkrieg empfand. ${ }^{175}$ Die talio aber, berechtigte Rache für die gewaltsame Tötung eines Nahestehenden, wird mit eben jener Formel umschrieben, die sich auch in Vers 32 findet: an-nafs bin-nafs, „Leben um Leben“ oder „Person um Person.“ Sie hat sich also durchgesetzt. Aber an letzterer Stelle, eben derjenigen, die von uns hier behandelt wird, ist sie erstaunlich. Denn nafs bedeutete kurz zuvor in Vers 30 noch die „Triebseele“; das kann hier nicht gemeint sein. ${ }^{176}$ Was besagt das für den Koran? Ist Vers 32, der ohnehin durch seine Länge auffällt, von anderswo hierher geraten? Während des Vorganges, den wir die „'utmānische Redaktion“ nennen,

169 Ähnlich schon oben S. 459 mit Anm. 43. Daß Kain Schuld hat für alle, ist ein Gedanke, der auch in der Mischna bereits begegnet; vgl. Yahuda 1948: 292f. Yahuda schließt aus dieser Parallele, daß die Juden der Arabischen Halbinsel nicht den Babylonischen Talmud benutzten, sondern den Jerushalmi. Vgl. das Ḥadìt bei Juynboll 2007: 106b.

170 Vgl. Speyer 1931: 87 f.; der Text ist übersetzt bei Cuypers 2009: 203.

171 Das Verbrechen wird hier als fasād fi l-arḍ bezeichnet; vgl. zu diesem Ausdruck Paret 1971: $13 \mathrm{f}$. zu Sure 2:11 f. Weiteres dazu bei Neuwirth 2017: 162 (zu Sure 17:33) und 177 (zu Sure 6:151). Zum Mord im Koran allgemein EQ: 3: 458 ff. s. v. Murder (Muh. Fadel); zu Sure 5:32 dort S. 459. 172 Also wenn er die šahāda ausspricht und sich damit als Muslim bekennt.

173 D. h. wenn jemand gesteinigt wird, weil er (oder sie) ein außereheliches Verhältnis eingegangen ist.

174 Zum Kontext vgl. van Ess Unfertige Studie 1: $1410 \mathrm{f}$.

175 S. o. S. 473 f. Nach Țabarī 1954-: 10: 239 nr. 11,798 geht diese Dreiteilung übrigens auf das Konto des Bașriers Qatāda b. Di‘āma; zu ihm o. S. 458.

176 Man sollte allerdings nicht übersehen, daß die Formulierung in Vers 32 noch nicht ganz entwickelt ist. Erst in Vers 45 lautet sie an-nafs bin-nafs; in Vers 32 heißt es noch nafs bi-gair nafs. In Vers 45 wird dann auch die talio genauer spezifiziert. Vgl. die Behandlung der beiden Stellen bei Cuypers 2009: 200 ff. und 240. „Seele“ wird im übrigen schon in der oben (Anm. 161) genannten jüdischen Vorlage im Sinne von „Person“ gebraucht. 
ist ja mit heißer Nadel genäht worden. Wir müssen auch diese Frage offen lassen.

Manche der von Țabarī zitierten Exegeten haben versucht, den Mord präziser - und nicht nur ex negativo - zu definieren, indem sie Sure 4:93 heranzogen: „Und wenn einer einen Gläubigen vorsätzlich tötet, ist die Hölle sein Lohn.“ Da ist dann klar, daß (wie im Fall eines Bürgerkrieges) an Muslime gedacht ist, die ermordet werden; die Tat geschieht im übrigen vorsätzlich (muta'ammidan). Diese Verknüpfung wird über 'Abdallāh b. al-Mubārak (gest. 181/797) ${ }^{177}$ und Ibn Ǧuraiğ (gest. 150/767) ${ }^{178}$ auf Muğāhid zurückgeführt: alladī yaqtulu n-nafs ${ }^{a}$ l-mu'mina ${ }^{\text {ta }}$ muta'ammid ${ }^{a n} \cdot{ }^{179}$ Sie geht dann ebenfalls in das Hadìt ein; Nasā'ī hat in seinem $K$. as-Sunan ein ganzes Kapitel über den Mord, ${ }^{180}$ in dem auch das Wort muta'ammidan (also der Vorsatz, der den Mord vom bloßen Totschlag unterscheidet) häufig vorkommt. ${ }^{181}$ Tabarī hält diese Interpretation des Verses für die beste. ${ }^{182}$ Aber es gab Sondervoten, in denen weiter eingeschränkt wurde: (Nur) wenn ein Prophet getötet wird oder ein gerechter Herrscher, ist das, als ob die ganze Menschheit getötet werde (also ein unersetzlicher Verlust). ${ }^{183}$ Andere versuchten, den Vers an ein bestimmtes Ereignis zu binden und ihm damit seine Allgemeingültigkeit zu nehmen; das führte zu einer langen Diskussion. ${ }^{184}$ Tabarī hingegen spricht sich dafür aus, daß der Vers für Muslime und ahl ad-dimma gleichermaßen gelte; ${ }^{185}$ es ging darin ja ohnehin um die Banū Isrā'îl. Wenn auf Erden Unheil gestiftet werde (fasād fi l-ard), spiele es keine Rolle, ob dieses Unheil von Muslimen ausgehe oder von Schutzbefohlenen aus einer andern Religion. Wenn dann in Vers 33, in einem neuen Abschnitt, die Rede auf diejenigen kommt, die „gegen Gott und Seinen Gesandten Krieg führen und (überall) im Land eifrig auf Unheil bedacht sind“, war man dem Bürgerkrieg wieder nahe. Die Exegeten waren sich einig, daß hier Räuber und Einbrecher gemeint seien, also doch wohl Muslime. ${ }^{186}$ Aber das geht uns jetzt nichts mehr an.

$177 \mathrm{Zu}$ ihm näher meine Unfertige Studie 4: 923, Anm. 90 und 961, Anm. 414.

$178 \mathrm{Zu}$ ihm oben Anm. 142.

179 Țabarī 1954-: 10: 235 nr. 11,778. Der Verweis auf Sure 4:93 auch in nr. 11,780 und 11,784-5.

180 Nasā'î 2000: 658-661 nr. 4003-4025 (=Tahrīm ad-dam 2).

181 Nasā'î 2000: 660 nr. 4017 ff. Wenn der Mörder dann behauptet, um der Ehre Gottes willen gehandelt zu haben (li-'izzat Allāh, also etwa im Falle der Blasphemie), hält Gott ihm Sure 5:29 entgegen (nr. 4014).

182 Țabarī 1954-: 10: 240, ult. ff.

183 Țabarī 1954-: 10: 232f. nr. 11,771-72.

184 Țabarī 1954-: 10: 244 ff. nr. 11,808-11,819.

185 Ṭabarī 1954-: 252, 5 ff.

186 Ṭabarī 1954-: 254f. nr. 11,820-28. 


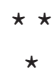

Ich habe in dem Material lediglich eine Auswahl getroffen. Zunächst nur „interesselose“ und zudem irregeleitete Wissenschaft, hat es unerwartete Aktualität gewonnen. Es ging mir aber auch nur um ein einziges Thema: das Weiterwirken von Abels Rede (Sure 5:29) in der Diskussion um das rechte Verhalten während der frühen Bürgerkriege. Die Argumentation wird sichtbar im Ḥadīt; aber sie verlor auf die Dauer ihren unmittelbaren Zeitbezug. Aktuell war sie in der Umaiyadenzeit; damals trieb man keine Theorie, sondern reagierte auf die Ereignisse selber, immer in zeitlicher Nähe, bevor das nächste aufwühlende Geschehen die Eindrücke verdrängte. Nach der abbasidischen „Revolution“ trat das Thema dann mitsamt den darin propagierten Parolen in den Hintergrund. Zwar war auch dieser Umsturz aus einem Bürgerkrieg erwachsen; aber er wurde - wohl aufgrund des geographischen Szenenwechsels (von Syrien zum Irak) - als der Anbruch einer neuen Zeit verstanden. Die Historiker nahmen die Argumente darum anscheinend nicht mehr auf. ${ }^{187}$ Das ist wichtig für die Chronologie.

Aber auch diese war nicht primär unser Anliegen. Wir haben uns jegliche Isnādanalyse versagt; wichtiger waren uns lokale Differenzen (Medina, Kūfa, Bașra). Im Mittelpunkt stand die Erzähltechnik. Die Argumente wurden ja nicht „an und für sich“ vorgebracht wie in einem politischen Gedankenaustausch, sondern waren eingepackt in eine Rahmengeschichte; dort spielten sie die Rolle von Modulen, die sich austauschen ließen und verschieden gewichtet werden konnten. Sie waren in gewissen Grenzen variabel und ließen sich auch in verschiedener Weise kombinieren. Wir befinden uns in einer „haggadischen“ Phase, ${ }^{188}$ die der Geschichtsschreibung vorausging. Die Module waren häufig lokal gebunden, wurden aber bald exportiert und dann der neuen Umgebung angepaßt. Im Laufe dieser Entwicklung mag „gefälscht“ worden sein; die bisherige Forschung hat diesen Aspekt stark hervorgehoben. Aber ausschlaggebend war nicht so sehr, daß man Geschichten „erfand“, sondern daß diese glaubwürdig sein mußten. Von daher wird sich auch die Chronologie am besten aufschlüsseln lassen. Dinge werden nämlich nur dann erzählt (und rezipiert), wenn ein Anlaß dazu besteht; andernfalls hört niemand zu. Man hat erzählt, um

187 In dem Ta'rīh al-Mauṣil des Abū Zakarīyā' Yazīd b. Muḥammad al-Azdī, gest. 334/945 (=Azdī 1967) tritt das Zitat bei der Schilderung des Massakers, das von abbasidischen Truppen unter Umaiyadenanhängern in Mosul veranstaltet wurde, nicht in Erscheinung, obwohl entsprechende Szenen evoziert werden (Azdī 1967: 132 ff.; dazu näher Robinson 2000: 127 ff.).

188 J. Wansbrough hat in seinen Quranic Studies diesen Begriff mit Bezug auf die frühe Koranexegese eingeführt (Wansbrough 1977: 122 ff.). 
bestimmte Probleme in den Griff zu bekommen, und man mußte dabei auf die mögliche Reaktion des Publikums Rücksicht nehmen. Die Erzähler waren keine Historiker, und auch die Zuhörer wollten anfangs nicht in erster Linie wissen, wie es früher einmal zugegangen war. Sie brauchten vielmehr Entscheidungshilfe durch das Beispiel und die Worte anerkannter Autoritäten, vor allem des Propheten. Ihr Interesse war nicht akademisch, und in den von uns behandelten Fällen standen sie vermutlich unter dem Schock einer bedrohlichen Gegenwart. Ihre Reaktionen sind früh, und diese sind manchmal wohl unmittelbar in den Erzählvorgang eingegangen. Allerdings weist das Material Schichten auf; es ist nicht einheitlich. Die Überlieferungen mußten sich auf die Dauer in jeweils wechselnde Geschichtsbilder einfügen; die Texte wurden dabei so umgeformt, daß sie in spätere Fragestellungen hineinpaßten. Es kam zu Verkürzungen und Erweiterungen; manches wurde auch ganz unterdrückt, weil es in den späteren „Überbau“ nicht mehr hineinpaßte. Hierher gehören die schon von Schacht beobachteten Rückdatierungen; man versuchte sie ebenso bei Personen wie bei Ereignissen. ${ }^{189}$ Aber diese Verschiebungen sind im allgemeinen leicht $\mathrm{zu}$ erkennen.

Die Erzählelemente sind nicht identisch mit literarischen Motiven. Indem sie auf Fragen antworten, die dem Publikum in den Sinn kommen konnten, sind sie eher Bruchstücke eines imaginären Dialogs. Gesprächsfetzen aus diesem Dialog drangen in den Text selber ein und konnten dann von einer Geschichte in die andere übertragen werden; das ist es, was wir an Sure 5:29 beobachten konnten. ${ }^{190}$ Daß ein Lehrender von seinen Hörern unterbrochen wird, ist bis heute im Orient zu beobachten. ${ }^{191}$ Der qāșs trat in der Umaiyadenzeit öffentlich auf, nicht selten im Auftrag der Obrigkeit; er sollte den Menschen seines Glaubens die

189 Für Personen vgl. o. S. 470 f. mit Anm. 131 f., für Ereignisse Anm. 76 und 129.

190 Man betrachte auch die Übereinstimmung zwischen der Reaktion des Propheten auf eine zu erwartende Blutrache („Wenn er ihn jetzt tötet, dann ist er wie er“, nämlich ebenfalls ein Mörder; s. o. S. 463) und der Reaktion des 'Abdallāh b. 'Umar auf eine öffentliche Hinrichtung, als er den Kopf des Toten auf einer Stange sieht: „Wer den getötet hat, ist (zur Hölle) verdammt“ (Ibn Ḥanbal 1946-1975: 8: 82f. nr. 5708; vgl. dazu oben Anm. 115). Man mag versuchen, dies im Sinne der alten Hypothese J. Schachts chronologisch zu ordnen, indem man das Prophetenhadìt später ansetzt als das Dictum des Prophetengenossen. Jedoch kann es sich auch um eine lokale Differenz handeln. Die Geschichte über Ibn 'Umar geht im übrigen nicht davon aus, daß der Hingerichtete ein Mörder gewesen sei. Das ist auch in der Variante bei Ibn Ḥanbal 1946-1975: 8: 124 nr. 5754 nicht der Fall, wo die Szene selber in der gleichen Weise imaginiert ist (s. o. Anm. 132).

191 Ich habe es selber in Qum gesehen, wo Āyatollāh Muntaziirī, damals schon politisch kaltgestellt, in seinem Hause einen kleinen Kreis von Studenten unterrichtete. Dasselbe war in der guten alten Zeit der deutschen Orientalistik der Fall, als man noch nicht Bachelor-Kandidaten mit pontifikaler Geste und „power-point“ mit Lernstoff versorgte. 
„Tradition“ ans Herz legen und dies bei Bedarf mit einer politischen Botschaft verbinden. ${ }^{192}$ Er versuchte die Vergangenheit $\mathrm{zu}$ erklären, indem er sich in die Erwartungen der Gegenwart hineinversetzte. Dabei konnten sich die Deutungsebenen verschieben; wir haben gesehen, wie das Modell einer Frühzeit, in der die ersten Menschen sich in einem religiösen Niemandsland moralisch und praktisch $\mathrm{zu}$ orientieren versuchten, durch die Annahme einer Uroffenbarung an Adam ergänzt (und zugleich gestört) wurde. ${ }^{193}$ Man empfand dies nicht als Systembruch; vielmehr ging beides zusammen in das kulturelle Gedächtnis der Muslime ein.

Allerdings hatte dieses kulturelle Gedächtnis in jenem riesigen Raum, wo der Islam sich ausbreitete, nicht überall die gleiche Gestalt. Tabarī macht den Sachverhalt deutlich, indem er die jüdisch-christliche Adam-Überlieferung mit der iranischen vom Urmenschen Gayōmart/Gayūmart verknüpft. ${ }^{194}$ Dieser Kulturvergleich ging nie ganz auf; für Ġazzālī z. B. ist Kayūmard nicht etwa der erste Mensch, sondern ein Bruder des Seth. ${ }^{195}$ Wir haben diesen Exkurs hier gar nicht berücksichtigt. Dagegen besteht Anlaß, sich zu fragen, ob die von uns behandelten Überlieferungen im arabischsprachigen Raum heute noch nachwirken. „Dieser Krieg hier in Libyen ist mein fünfter in vier Jahren. Aber er ist anders als alle Kriege zuvor. Der Prophet hat ihn vorhergesagt. Daß ein Krieg kommt, mit dem das Ende unserer Welt beginnt.“ So sagte ein Panzerschütze, eigentlich Elektriker von Beruf, als er in der libyschen Küstenstadt Sirte (die ihren Namen von unserer „Großen Syrte“ hat) gegen die Eindringlinge von Da'iš (ad-daula alislāmīya fì l-'Irāq waš-Ša'm), unserem IS, zu Felde zog. ${ }^{196}$ Der Bruderkrieg, in dem er sich befand, trug für ihn endzeitliche Züge. Das hatte man schon einmal zum Thema gemacht - tiefer vermutlich, aber erfolglos. Unser Panzerschütze dachte nicht daran, sein „Schwert zu zerbrechen“, und daß ihm wie seinem Gegner, dem Töter wie dem Getöteten, die Hölle sicher sei, wird er wohl auch nicht geglaubt haben. Wo hätte je ein kulturelles Gedächtnis die Menschen davon abgehalten, weiteres Unheil zu stiften? Wer durch seinen Einsatz für eine „gerechte Sache“ ins Paradies zu kommen hofft, findet eher Gehör. ${ }^{197}$

192 Vgl. EI²: 4: 733-35 s. v. kāss (Ch. Pellat); auch Pedersen 1948 und Athamina 1992, zuletzt Armstrong 2017.

193 S. o. S. $455,457$.

194 Ṭabarī 1879-1901: 1: 147, 3 ff. und 154, 2 ff. / übs Ṭabarī 1989: 318 f. und 325 ff.

195 Vgl. EIr: 10: 345 ff. s. v. Gayōmart (Mansour Shaki).

196 „Die Zeit“ vom 14. Juli 2016, dort S. 13.

197 Endzeitliche Gedanken kursierten in der arabischen Welt auch 1967, nach dem Ende des Sechstage-Krieges. Das lag daran, daß Moshe Dayan eine Augenklappe trug; auch der Dağǧāl, der „Antichrist“ der Muslime, wird als einäugig vorgestellt. Aber dieser Krieg war kein Bruderkrieg. - Ein ähnlicher Querstand im kulturellen Gedächtnis ist im Alten Testament zu beobachten. Als die Israeliten während Moses Abwesenheit am Sinai das Goldene Kalb verehrt hatten, soll dieser nach 
Danksagung: Ich danke Johannes Thomann (Universität Zürich) für sein Engagement und seine Unterstützung bei der redaktionellen Fertigstellung dieses Beitrags.

\section{Bibliographie}

Abū Dāwūd, Sulaimān b. al-Aš'at (2000): As-Sunan. Liechtenstein: Thesaurus Islamicus Foundation.

Abū Nu'aim, Aḥmad b. 'Abdallāh al-Iṣfahānī (1932-1938): Ḥilyat al-auliyā' wa-ṭabaqāt alașfiyā'. Kairo [Nachdruck Beirut: Dār al-kitāb al-'arabī 1967].

Aguadé, Jorge (1979): Messianismus zur Zeit der frühen Abbasiden. Das K. al-Fitan des Nu'aim ibn Hammād. Diss. Tübingen.

Armstrong, Lyall R. (2017): The Qușșās of Early Islam. Leiden: Brill.

Asatryan, Mushegh (2017): Controversies in Formative Shi'i Islam. The Ghulat Muslims and Their Beliefs. London: Tauris.

Athamina, Khalil (1992): “Al-Qașaș. Its Emergence, Religious Origin and Its Socio-political Impact on Early Muslim Society". Studia Islamica 76: 53-74.

Azdī, Abū Zakarīyā' Yazīd b. Muḥammad al- (1967): Ta'rīh al-Mauṣil. Hrsg. von 'Alī Ḥabība. Kairo: al-Mağlis al-a'lā liš-šu'ūn al-islāmīya 1387 H.

Bachelard, Gaston (1937): La psychanalyse du feu. [ $\left[{ }^{11}\right.$ Paris, Gallimard 1949]; dt. Psychoanalyse des Feuers. München 1985.

Bell, Richard (1991): A Commentary on the Qur'ān. Hrsg. von C. E. Bosworth und M. E. J.

Richardson. Manchester: University of Manchester (Journal of Semitic Studies Monograph 14).

Bezold, Carl (1883-1888): Die Schatzhöhle. Leipzig: Hinrichs.

Bork-Qaysieh, Waltraud (1993): Die Geschichte von Kain und Abel in der sunnitisch-islamischen Überlieferung. Untersuchung von Beispielen aus verschiedenen Literaturwerken unter Berücksichtigung ihres Einflusses auf den Volksglauben. Berlin: Diss. Freie Universität.

Busse, Heribert (2001): “Cain and Abel” In: EQ I 270 ff.

Busse, s. auch unter Ta'labī.

Charles, Robert Henry (1902): The Book of Jubilees or the Little Genesis. Mit einer Einleitung von G. H. Box. London: Society for Promoting Christian Knowledge.

Conc. $=$ Wensinck, Arent Jan (1936-1988): Concordance et indices de la Tradition musulmane. Leiden: Brill.

Cook, David (2017): The Book of Tribulations: the Syrian Muslim Apocalyptic Tradition. Edinburgh: Edinburgh Univeristy Press.

Crone, Patricia (1984): “Jāhilī and Jewish Law. The Qasāmah”. Jerusalem Studies in Arabic and Islam 4: 153-201.

seiner Rückkehr zu den „Kindern Levi“ gesagt haben: „Gürte ein jeglicher sein Schwert .... und erwürge seinen Bruder, Freund und Nächsten.“ (Ex. 32:27) - eine Aufforderung zum Bürgerkrieg. Aber die „Brüder“ und „Nächsten“ waren ja auch vom Glauben abgefallen. 
Cuypers, Michel (2007): Le festin. Une lecture de la sourate al-Mā'ida. Paris: Lethielleux. Englische Übersetzung (P. Kelly 2009): The Banquet. A Reading of the Fifth Sura of the Qur'an. Miami: Convivium Press.

Cuypers, Michel (2009): The Banquet: A Reading of the Fifth Sura of the Qur'an. Miami: Convivium.

Dahabī, Muḥammad b. Aḥmad ad- (1963-1965): Mīzān al-i'tidāl fì naqd ar-riğāl. Hrsg. von 'Alī Muḥammad al-Biǧāwīi. Kairo: Dār lḥyā' al-Kutub al-'arabīya 'T̄sā al-Bābī al-Ḥalabī.

$\mathrm{El}^{1}=$ Houtsma, Martin Theodor (Hrsg.) (1913-1938): Encyklopädie des Islam: geographisches, ethnographisches und biographisches Wörterbuch der muhammedanischen Völker. Leiden: Brill.

$\mathrm{El}^{2}=$ Bosworth, Clifford Edmund (Hrsg.) (1960-2009): The Encyclopaedia of Islam. Leiden: Brill. $\mathrm{EQ}=$ Encyclopedia of the Qur'ān (2001-2006). Hrsg. von Jane Dammen McAuliffe. Leiden: Brill. GAS = Sezgin, Fuat (1967-): Geschichte des arabischen Schrifttums. Leiden: Brill.

Gilliot, Claude (2013): “A Schoolmaster, Storyteller, Exegete and Warrior at Work in Khurāsān: al-ḍaḥḥāk b. Muzāḥim al-Hilālī”. In: Aims, Methods and Contexts of Qur'anic Exegesis. Hrsg. von Karen Bauer. Oxford: Tauris, 311-392.

Gilliot, Claude (2014): “Mujāhid's Exegesis. Origins, Paths of Transmission and Development of a Meccan Exegetical Tradition in its Human, Spiritual and Theological Environment". In: Tafsir and Islamic Intellectual History. Hrsg. von Andreas Görke und Johanna Pink. New York: Oxford University Press, 63-112.

Gimaret, Daniel (1994): Une lecture mu'tazilite du Coran. Le Tafsīr d'Abū 'Alī al-Djubbā'î (m. 303/915) partiellement reconstitué à partir de ses citateurs. Louvain: Peeters. (Bibliothèque de l'Ecole des Hautes Etudes. Sciences Religieuses. Vol. Cl).

Gramlich, Richard (1997): Weltverzicht. Grundlagen und Weisen islamischer Askese. Wiesbaden: Harrassowitz. (Ak. Wiss. Mainz: Veröffentlichungen der Orientalischen Kommission 43).

Haitamī, 'Alī b. Abī Bakr al- (1982): Mağma' az-zawā'id wa-manba' al-fawā'id. Nachdruck Beirut: Dār al-Kitāb al-'arabī.

Ḥākim an-Naisābūrī, Muḥammad b. 'Abdallāh al- (1915-1923): Al-Mustadrak 'alā ṣ-ṣaḥịhain. Haidarabad: Dā'irat al-ma'ārif al-islāmīya 1334-1342 H.

Halīfa b. Ḩaiyāț, Abū 'Amr al-'Ușfurī (1966): Aț-Tabaqāt. Hrsg. von Suhail Zakkār. Damaskus: Wizārat at-Taqāfa was-siyāḥa wal-iršād al-qaumī, Nr. 14.

Halīfa b. Ḩaiyāț, Abū 'Amr al-'Uṣfurī (1967-1968): At-Ta'rīhh. Hrsg. von Suhail Zakkār. Damaskus: Wizārat at-Taqāfa was-siyāḥa wal-iršād al-qaumī, Nr. 17.

Ibn 'Abdalbarr, Yūsuf b. 'Abdallāh (um 1960): Al-Istī'āb fĩ ma'rifat al-așḥāb. Hrsg. von 'Alī Muḥammad al-Biğāwī): Kairo: Mațba'at Nahụat Mișr.

Ibn al-Atīir, al-Mubārak b. Muḥammad (1963): An-Nihāya fĩ garīb al-ḥadīt wal-atar. Hrsg. von Ṭāhir Aḥmad az-Zāwī. Kairo: 'T̄sā al-Bābī al-Ḥalabī.

Ibn Ḥağar al-'Asqalānī, Aḥmad b. 'Alī (1907-1909): Tahdīb at-Tahdīb. Haidarabad: Dā’irat alma'ārif an-Niẓāmīya.

Ibn Ḥağar al-'Asqalānī, Aḥmad b. 'Alī (1964-1967): Tabșīr al-muntabih bi-taḥrīr al-Muštabih. Hrsg. von 'Alī Muḥammad al-Biğāwī. Kairo: al-Mu'assasa al-Miṣrīya al-‘āmma lit-ta'līf walanbā' wan-našr.

Ibn Ḥanbal, Aḥmad b. Muḥammad (1895): Al-Musnad. Kairo: al-Maktab al-Islāmī.

Ibn Ḥanbal, Aḥmad b. Muḥammad (1946-1975): Al-Musnad. Hrsg. von Aḥmad Muḥammad Šākir. Kairo: Dār al-ma'ārif (unvollständig).

Ibn Māğa, Muḥammad b. Yazīd (1952): As-Sunan. Hrsg. von Muḥammad Fu'ād 'Abdalbāqī. Kairo: 'T̃sā al-Bābī al-Ḥalabī 1352 H. 
Ibn Māğa, Muḥammad b. Yazīd (2000): As-Sunan. Liechtenstein: Thesaurus Islamicus Foundation.

Ibn Manẓūr, Ǧamāladdīn Muhammad b. Mukarram (1955): Lisān al-'Arab. Beirut: Dar Sader. Ibn Qutaiba, 'Abdallāh b. Muslim (1969): Kitāb al-Ma'ārif. Hrsg. von Tarwat 'Ukāša. Kairo: Dār al-Ma'ārif.

Ibn Qutaiba, 'Abdallāh b. Muslim (Pseudo-) (1967): al-Imāma was-siyāsa. Hrsg. von Ṭāhā Muḥammad az-Zainī. Kairo: Mu'assasat al-Ḥalabī.

Ibn Sa'd, Muḥammad (1904-1917): Kitāb aț-ṭabaqāt al-kabīr. Hrsg. von Eduard Sachau u. a. Leiden: Brill.

Juynboll, Gauthier H. A. J. (1973): “The Date of the Great Fitna”. Arabica 20: 142-159.

Juynboll, Gauthier H. A. J. (1991): "The Role of Mu'ammarūn in Early Development of the Isnād”.

Wiener Zeitschrift für die Kunde des Morgenlandes 81: 155-175.

Juynboll, Gauthier H. A. J. (2007): Encyclopedia of Canonical Hadith. Leiden: Brill.

Khoury, Adel Theodor (1990-2001): Der Koran arabisch-deutsch. Übersetzung und wissenschaftlicher Kommentar. Gütersloh: G. Mohn.

Kister, M. J. (1977): "The Battle of the Harra. Some Socio-Economic Aspects". In: Studies in Memory of Gaston Wiet. Hrsg. von Myriam Rosen-Ayalon. Jerusalem: Institute of Asian and African Studies.

Krämer, Gudrun (2005): Geschichte des Islam. Bonn: Bundeszentrale für politische Bildung. Lane, Edward William (1863-1893): An Arabic-English Lexicon: Derived from the Best and Most Copious Eastern Sources. London: Williams and Norgate.

Lexikon der christlichen Ikonographie (1968-1976). Hrsg. von Engelbert Kirschbaum u. a. Rom/ Freiburg: Herder.

Littmann, Enno (1900): „Das Buch der Jubiläen“. In: Apokryphen und Pseudepigraphen des Alten Testaments. Zweiter Band: Die Pseudepigraphen des Alten Testaments. Edited by E. Kautzsch. Tübingen: Mohr (Paul Siebeck), 31-119 [nachgedruckt 1921 und 1962].

Marzolph, Ulrich (2017): "An Early Persian Precursor to the Tales of Sindbād the Seafaring Merchant”. Zeitschrift der Deutschen Morgenländischen Gesellschaft 167: 127-141.

Muslim b. al-Ḥaǧğāğ (1955-1956): Aṣ-Șaḥị̣. Hrsg. von Muḥammad Fu'ād 'Abdalbāqī. Kairo: 'Īsā al-Bābī al-Ḥalabī.

Nasā'î, Aḥmad b. 'Alī b. Šu'aib an- (2000): As-Sunan. Liechtenstein: Thesaurus Islamicus Foundation.

Neuwirth, Angelika (2017): Die koranische Verzauberung der Welt und ihre Entzauberung in der Geschichte. Freiburg: Herder.

Nu'aim b. Ḥammād b. Mu'āwiya al-Hูuzā'ī (1991): Kitāb al-Fitan. Hrsg. von Samīr Amīn azZuhairī. Kairo: Maktabat at-Tauhīi $1412 \mathrm{H}$.

Paret, Rudi (1971): Der Koran. Kommentar und Konkordanz. Stuttgart: W. Kohlhammer.

Pedersen, Johannes (1948): “The Islamic Preacher: wā'iz̧, mudhakkir, qāșș”. In: Ignace Goldziher Memorial Volume I. Hrsg. von Samuel Löwinger und Joseph Somogyi. Budapest: Globus Nyomdai Muintezet, 226-251.

Phenix, Robert R. (2013): “Adam's Offspring, Male and Female: Comparative Perspectives on a Trajectory in Jewish, Syriac Christian, and Early Islamic Literature”. In: The Bible, the Qur'an, and Their Interpretation. Syriac Perspectives. Edited by C. Horn. Warwick: Abelian Academic, 1-14.

Pregill, Michael (2008): "Isrā'iliyyāt, Myth, and Pseudepigraphy. Wahb b. Munabbih and the Early Islamic Versions of the Fall of Adam and Eve". Jerusalem Studies in Arabic and Islam 34: 215-284.

Reckendorf, Hermann (1921): Arabische Syntax. Heidelberg: Winter. 
$\mathrm{RGG}^{4}=$ Religion in Geschichte und Gegenwart. Handwörterbuch für Theologie und Religionswissenschaft (1998-2007). Vierte, völlig neubearbeitete Auflage. Hrsg. von H. D. Betz u. a. Tübingen: Mohr Siebeck.

Robinson, Chase (2000): Empire and elites after the Muslim conquest. Cambridge: University Press.

Rotter, Gernot (1992): Die Umaiyaden und der Zweite Bürgerkrieg (680-692). Wiesbaden: Steiner. (Abhandlungen für die Kunde des Morgenlandes; Bd. 45, Nr. 3).

Sidersky, David (1933): Les origines des légendes musulmanes dans le Coran et dans les vies des prophètes. Paris: Geuthner.

Speyer, Heinrich (1931): Die biblischen Erzählungen im Qoran. Gräfenheinichen 1931. [Nachdruck 1961. Hildesheim: Olms.].

Stillman, Norman A. (1974): "The Story of Cain and Abel in the Qur'an and the Muslim Commentators. Some Observations”. Journal of Semitic Studies 19: 231-239.

Ṭabarī, Muḥammad b. Ǧarīr aț- (1879-1901): Annales = Ta'rīh ar-rusul wal-mulūk. Hrsg. von Michael Jan de Goeje. Leiden: Brill.

Ṭabarī, Muḥammad b. Ǧarīr aț- (1954-): At-Tafsīr = Ǧāmi' al-bayān 'an ta'wīl āy al-Qur'ān. Hrsg. von Mạ̣mūd Muḥammad Šākir. Kairo: Dār al-ma'ārif (unvollständig).

Ṭabarī, Muḥammad b. Ǧarīr aț- (1989): The History of al-țabarī. Bd. I: From the Creation to the Flood. Translated and annotated by Franz Rosenthal. Albany, NY: State University of New York Press.

Ṭabarī, Muḥammad b. Ǧarīr aț- (1991): The History of al-țabarī. Bd. III: The Children of Israel. Translated and annotated by William M. Brinner. Albany, NY: State University of New York Press.

Talaat, Sia (1929): Die Seelenlehre des Korans mit besonderer Berücksichtigung der Terminologie. Diss. Halle.

Talaat, Sia (1929): Die Seelenlehre des Korans (mit besonderer Berücksichtigung der Terminologie). Halle (Saale): John.

Ta'labī, Abū Isḥāq Aḥmad b. Muḥammad b. Ibrāhīm at- (2006): 'arā'is al-mağălis. Übs. und komm. von Heribert Busse u. d. T. Islamische Erzählungen von Propheten und Gottesmännern. Wiesbaden: Harrassowitz. (Diskurse der Arabistik 9).

Ta'rīh Bag̀dād = Ahmad b. 'Alī al-Hațīb al-Bag̉dādī (1931): Ta'rīh Bag̉dād. Kairo: Maktabat alHānğī.

Tayob, Abdulkader (1993): "An analytical survey of al-țabarī’s exegesis of the cultural symbolic construct of fitna”. In: Approaches to the Qur'ān. Hrsg. von G. Hawting und Abdul-Kader A. Shareef. London: Routledge, 157-182.

TG $=$ van Ess 1991-1997.

Torrey, Charles Cutler (1892): The Commercial-Theological Terms in the Koran. Leiden: Brill.

Ullmann, Manfred (1970): Die Medizin im Islam. Leiden: Brill. (Handbuch der Orientalistik, Erste Abt., Ergänzungsband VI. Erster Abschnitt).

van Ess, Josef (1961): Die Gedankenwelt des Ḥārit al-Muḥāsibī. Bonn: Selbstverlag des Orientalischen Seminars der Universität Bonn (Neue Serie 12).

van Ess, Josef (1971): Frühe mu'tazilitische Häresiographie. Zwei Werke des Nāši' al-akbar (gest. 293 H.). Wiesbaden: Steiner (Beiruter Texte und Studien 11).

van Ess, Josef (1972): Das Kitāb an-Nakt des Nažāām. Göttingen: Vandenhoek und Ruprecht. (Abh. Ak. Wiss. Göttingen, Phil.-Hist. Klasse III 79).

van Ess, Josef (1991-1997): Theologie und Gesellschaft im 2. und 3. Jahrhundert Hidschra. Eine Geschichte des religiösen Denkens im frühen Islam. Berlin: Walter de Gruyter. [Engl. Übs. Leiden: Brill 2016-2019.]. 
van Ess, Josef (2001): Der Fehltritt des Gelehrten. Die „Pest von Emmaus“ und ihre theologischen Nachspiele. Heidelberg: Winter.

van Ess, Josef (2014): „Neue Fragmente aus dem K. an-Nakt des Naẓz̄ām“. Oriens 42: 20-94.

van Ess, Josef (2016): „Unfertige Studien 1. Wer sind und was bedeutet al-märiqa ?“. Asiatische Studien 70: 1389-1431.

van Ess, Josef (2018a): Kleine Schriften. Ed. by Hinrich Biesterfeldt. Leiden: Brill.

van Ess, Josef (2018b): „Unfertige Studien 4. Skrupelhaftigkeit“. Asiatische Studien 72: 909-1005.

van Ess, Josef (2019): „Unfertige Studien 5. Angeberei und Sufikleidung“. Asiatische Studien 73: 121-147.

Wansbrough, John (1977): Quranic Studies. Sources and Methods of Scriptural Interpretation. Oxford: Oxford UP.

Yahuda, Abraham Shalom (1948): “A Contribution to Qur'ān and Ḥadīth Interpretation”. In: Ignace Goldziher Memorial Volume I. Hrsg. von Samuel Löwinger, Joseph Somogyi. Budapest: Globus Nyomdai Muintezet, 280-308.

Zamahšarī, Maḥmūd b. 'Umar az- (1945): Al-Fā'iq fí garīb al-ḥadīt. Hrsg. von 'Alī Muḥammad alBiǧāwī und Muḥammad Abū l-Faḍl Ibrāhīm. Kairo: Dār lḥyā' al-Kutub 1364 H.

Supplementary Material: The online version of this article offers supplementary material (https://doi.org/10.1515/asia-2020-0003). 
Special section:

Glocalization Narratives in Indian Literature and Cinema 